\title{
Hostile Takeovers in the 1980s: The Return to Corporate Specialization
}

\section{Citation}

Bhagat, Sanjai, Andrei Shleifer, Robert W. Vishny. 1990. Hostile takeovers in the 1980s: the return to corporate specialization. Brookings Papers on Economic Activity. Microeconomics 1990: 1-84.

\section{Published Version}

http://www.jstor.org/stable/2534780

\section{Permanent link}

http://nrs.harvard.edu/urn-3:HUL.InstRepos:8705861

\section{Terms of Use}

This article was downloaded from Harvard University's DASH repository, and is made available under the terms and conditions applicable to Other Posted Material, as set forth at http:// nrs.harvard.edu/urn-3:HUL.InstRepos:dash.current.terms-of-use\#LAA

\section{Share Your Story}

The Harvard community has made this article openly available.

Please share how this access benefits you. Submit a story.

\section{Accessibility}


S A N J A I B HAGAT

University of Colorado

ANDREI SHLEIFER

University of Chicago

ROBERT W. VISHNY

University of Chicago

\section{Hostile Takeovers in the 1980s: The Return to Corporate Specialization}

HoSTILE TAKEOVERS invite strong reactions, both positive and negative, from academics as well as the general public. Yet fairly little is known about what drives these takeovers, which characteristically involve significant wealth gains to target firms' shareholders. The question is where these wealth gains come from.

We examine the sample of all 62 hostile takeover contests between 1984 and 1986 that involved a purchase price of $\$ 50$ million or more. In these contests, 50 targets were acquired and 12 remained independent. We use a sample of hostile takeovers exclusively to avoid using evidence from friendly acquisitions to judge hostile ones, as many studies have done. We examine such post-takeover operational changes as divestitures, layoffs, tax savings, and investment cuts to understand how the bidding firm could justify paying the takeover premium. We also examine the possibility of wealth losses by bidding firms' stockholders as the explanation for target shareholder gains.

The analysis of post-takeover changes is complicated because once the target and the bidding firms are merged, it becomes impossible to attribute to the target the changes recorded in joint accounting data. As a consequence, we do not use such data, but rather focus on discussion in annual reports, $10 \mathrm{~K}$ forms, newspapers, magazines, Moody's and

We would like to thank Dennis Carlton, Eugene Fama, Kenneth Frenchy, Gregg Jarrell, Michael Jensen, Steve Kaplan, René Stulz, and Lawrence Summers for comments and the Bradley Foundation for financial support. 
Value Line reports, and other such sources. Our approach is similar to the one recently employed by Bhide (1989). The advantage of this design is that we can attribute the changes we examine, such as layoffs and selloffs, to the target firm. The disadvantage is that most changes we examine are biased downward because some may not be reported.

Our calculations suggest that, on average, taxes and layoffs each explain a moderate fraction of the takeover premium. Layoffs, which disproportionately affect high-level white-collar employees, explain perhaps 10-20 percent of the average premium, although in a few cases they are the whole story. Tax savings are usually somewhat smaller than savings from layoffs (although they are significant in a larger number of cases), since debt is typically repaid fairly fast. But tax reductions are very large in management buyouts, acquisitions by partnerships, and acquisitions by firms with tax losses. Large investment cuts occur infrequently in our sample, and do not appear to be an important takeover motive. Wealth declines of the bidding firms' shareholders, similarly, while important in a few cases, are usually small and cannot be a systematic source of target shareholders' gains.

Our most significant finding is that most hostile takeover activity results in allocation of assets to firms in the same industries as those assets. In most hostile takeovers, the bidding firm is in the same business as, or a business closely related to, that of the target firm. Similarly, the majority of selloffs, which amount to 30 percent of the acquired assets, are to buyers in the same business as the assets they acquire. Overall, of the assets that changed hands in our sample, 72 percent ended up owned by corporations with other similar assets. By and large, hostile takeovers represent the deconglomeration of American business and a return to corporate specialization.

These findings have significant implications for explaining the sources of gains in hostile takeovers. First, they suggest that the places to look for the gains are cost savings from joint operations, market power, or possibly overpayment by buyers of divisions and whole companies. Some of these gains might be from eventual layoffs that we document, but others we might not be able to capture. In any event, changes that result from consolidation of industries are essential for understanding takeover gains. Second, the findings suggest that incentive-intensive organizations, such as management buyout teams, investment companies, or raiders, are not very important in the long run. In our sample, 
only 20 percent of the assets ended up under control of such organizations after two to three years, and this fraction would surely dwindle if we looked at the assets over a longer period. Control by raiders or by $\mathrm{MBO}$ teams is often a transitory arrangement used to allocate assets to corporations managing other similar assets.

\section{Potential Sources of Takeover Gains}

What is the source of target shareholders' gains in hostile takeovers? The literature offers a wealth of theories of the sources of takeover gains in general. One possibility is simply that the stock market underprices the target, so that no operational changes are actually needed for the bidder to profit from the acquisition. Another possibility is that bidding firms overpay for their targets, perhaps because acquisitions serve the objectives of managers and not of shareholders. In these cases the target shareholders' gains are the bidding shareholders' losses. Consistent with this view is the evidence of David Ravenscraft and F. M. Scherer that the earnings of acquired lines of business in the friendly takeovers of the 1960 s and 1970 s did not rise. ${ }^{1}$

Although underpricing and bidder overpayment might be important, they are probably not the whole story in hostile takeovers. For example, Steven Kaplan shows that cash flow (net of capital expenditures) rises significantly in his sample of LBOs. ${ }^{2}$ Moreover, substantial anecdotal evidence also indicates that hostile takeovers are followed by large operational changes in many firms. Accordingly, we first deal with the role of wealth changes in bidding firms' shareholders, and then describe some potentially important changes that can justify takeover premiums, as well as discuss how these sources fit into existing takeover theories.

\section{Wealth Change of Bidding Shareholders}

Target shareholders in hostile takeovers clearly gain significant wealth, but less is known about bidding shareholders. If they gain as well, then the analysis of operational changes must come up with greater savings

1. Ravenscraft and Scherer (1987).

2. Kaplan (1990). 
to account for the wealth gains. If, on the other hand, bidding shareholders lose, a smaller shareholder wealth increase is left to explain.

Many argue that competition between actual and potential bidders, as well as the ability of target shareholders to "free ride" on gains, ensures that most of the gains in takeovers accrue to the target firm's shareholders. Bidding shareholders gain from a takeover to the extent that there is a component to the value gain that is not lost through competition and cannot be appropriated by target shareholders. Such bidder gains might be particularly large when the bidder and the target are in the same industry, and special opportunities to the given merger are not available to other bidders. Considerable evidence, however, shows that many mergers are driven by managerial rather than shareholder objectives, which make bidding firms willing to overpay for the acquisition targets. Overpayment, of course, leads to negative returns to bidding shareholders.

The evidence is that the bidders just about break even, but the findings vary by time period and the type of acquisition. No studies examine bidder returns in hostile takeovers; the only proxy for such evidence is the finding for tender offers. In the 1980s, bidders in tender offers lost small amounts of wealth on average ${ }^{3}$ This evidence suggests that many acquisitions are driven by the objectives of managers rather than of shareholders, so that managers are willing to overpay for the targets to pursue their own goals. In a sample of mostly friendly acquisitions, Randall Morck, Andrei Shleifer, and Robert Vishny find that bidding shareholders are more likely to lose when acquisitions serve managerial objectives, such as diversification and pursuit of growth. ${ }^{4}$ Since there are many "strategic" acquisitions in our sample, we examine the changes in the wealth of bidding shareholders as one potential source of gains of the target firms' shareholders.

\section{Strategic Acquisitions}

As noted, hostile takeovers often involve the acquisitions of firms closely related to the bidding firm. Gains from related acquisitions are likely to come from operating efficiencies (either pure efficiency gains or wealth transfers) or from increased market power. Gains from market

3. Bradley, Desai, and Kim (1988).

4. Morck, Shleifer, and Vishny (1990). 
power are commonly believed to have driven the horizontal mergers preceding World War II, before the strict antitrust enforcement of the 1960 s and 1970s made such mergers more difficult. ${ }^{5}$ With the relaxation of antitrust enforcement during the 1980s, many horizontal combinations once again became possible. Some argue that the gains in some strategic acquisitions come from this ability to restrict output and raise price.

Some evidence on the importance of such acquisitions comes from the findings of Espen Eckbo and Robert Stillman that competitors' stock prices rise when horizontal mergers are announced, consistent with the simple model of declining competition. ${ }^{6}$ However, stock prices of competitors do not rise nearly as much as those of the target, as a simple oligopoly model would predict. Furthermore, competitors' stock prices sometimes also rise when the government challenges the initial merger, which seems contrary to the oligopoly theory. Although this evidence is still being debated, it suggests that market power is not the whole story.

Joint operating efficiencies might come from combining research and development, procurement, distribution, marketing, and headquarters operations. Some of these operating efficiencies are reflected in layoffs and other cuts, but others are harder to capture. These gains might be all the greater if the target is not well run to begin with and is acquired by a firm with better managers who find more ways to reduce costs.

With the exception of labor cost savings (discussed later), the evidence on efficiency improvements after hostile takeovers is still indirect. Morck, Shleifer, and Vishny find that targets of hostile takeovers have low Tobin's $q$ 's relative to their industry peers and also that industries with significant hostile activity have low $q$ 's ${ }^{7}$ Henri Servaes finds that bidding firms in tender offers have higher $q$ 's than do the targets. ${ }^{8}$ This evidence points to better performers taking over poor performers. Servaes also finds that premiums are higher when the target's $q$ is lower, suggesting that there are greater efficiencies to realize. Unfortunately, it can also mean that targets are undervalued or that bidding firms are overvalued and so have a low cost of capital.

5. Stigler (1950).

6. Eckbo (1983) and Stillman (1983).

7. Morck, Shleifer, and Vishny $(1988,1989)$.

8. Servaes (1989). 
We do not have the data to identify the sources of gains in strategic acquisitions, other than layoffs. Accordingly, we simply identify acquisitions that appear to have an important strategic element, and try to determine how prevalent they are in the hostile takeover process. We present some examples in which operating efficiencies were realized as well as some examples with the potential for increased market power. The question of the sources of gains in general remains open, and it is not clear to us that any simple description of synergistic gains in related acquisitions will fit the data. We base this conclusion on an examination of all the accounts (qualitative and quantitative) of our sample takeovers that we could find. The takeovers are summarized in the appendix.

\section{Labor Cost Savings}

Labor costs are by far the largest component of costs in most corporations. Labor cost savings can therefore be one of the most effective ways to increase cash flow. Such savings can take a number of forms, including layoffs, early retirements, hiring freezes, wage reductions, reductions in future pension benefits, and other cuts in compensation. If some of the employees in the firm are paid more than their marginal product, then laying them off or cutting their pay can increase the cash flow and so justify some of the premium.

Previous studies have examined the extent of labor cost savings. Joshua Rosett considers wage reductions of union employees and finds that they can explain, at most, 9 percent of the takeover premium. ${ }^{9}$ Interestingly, up to 21 percent of the premium can be explained for the subsample in which the chief executive officer changes after the takeover. However, the wage changes are not reliably different from zero in most specifications. Andrei Shleifer and Lawrence Summers present evidence of substantial wage reductions in one hostile takeover-Icahn's acquisition of TWA-that are large enough to more than justify the takeover premium. ${ }^{10}$ They have only one famous case, however.

Wages, of course, are not the only form of compensation. Jeffrey Pontiff, Andrei Shleifer, and Michael Weisbach present evidence of reversions of excess pension assets following hostile takeovers, and 
document the greater incidence of such reversions following hostile takeovers than following friendly acquisitions. ${ }^{11}$ They estimate that reversions can explain about 13 percent of the takeover premium in cases where they actually occur, but they occur in only 10 percent of cases. Pontiff, Shleifer, and Weisbach argue that pension asset reversions represent a cut in future benefits to the employees. Although these reversions are a potentially important source of takeover gains in a few cases, on average they are relatively unimportant.

Overall, the available evidence on compensation cuts of existing workers does not suggest that such cuts are an important source of takeover gains in many cases.

A second way to save on labor costs is to reduce employment. Charles Brown and James Medoff examine control changes in small Michigan companies and find no evidence of employment reductions. ${ }^{12}$ They do not appear to have a single hostile takeover in their sample. In an early version of his paper, Steve Kaplan finds some evidence of employment reductions after defensive MBOs that follow hostile bids. ${ }^{13}$ There is no evidence of employment reductions following friendly MBOs. Kaplan does not estimate the value of savings from these reductions. Frank Lichtenberg and Donald Siegel find evidence of substantial employment reductions surrounding (and mostly preceding) ownership changesand not necessarily hostile takeovers. ${ }^{14}$ They also find that such reductions are primarily among white-collar employees. All these findings point to the potential importance of employment reductions, although the studies do not estimate how much money is saved and do not draw an adequate distinction between hostile and friendly takeovers.

In discussing layoffs, it is important to keep in mind the normative interpretation of employment reductions. One view, taken by Lichtenberg and Siegel, is that employment reductions of headquarters personnel in particular represent a pure efficiency gain. ${ }^{15}$ Michael Jensen also argues that employment reductions improve efficiency. ${ }^{16}$ Shleifer

11. Pontiff, Shleifer, and Weisbach (1989).

12. Brown and Medoff (1988).

13. Kaplan (1990).

14. Lichtenberg and Siegel (1988).

15. Lichtenberg and Siegel (1988).

16. Jensen (1988). 
and Summers, in contrast, stress the importance of long-term implicit contracts in employment relationships. ${ }^{17}$ They do not deny that ex post layoffs might be efficient; rather, they suggest that if continued employment is part of the implicit contract, layoffs represent a breach of trust that transfers future wages in excess of marginal product from employees to shareholders. Moreover, the efficiency gain from moving workers across firms may be much smaller than their lost wages.

We cannot determine what happens to laid-off workers after the takeover and how much their compensation falls. The transfer component should be measured by the present value of the difference between current wages and alternative wages. In this paper we attempt to measure the wage savings from takeovers and to compare them with the takeover premium. We cannot determine what fraction of these savings is an efficiency gain and what fraction is a transfer. The conclusion that everything is an efficiency gain is premature, given the universal employee insistence that takeovers reduce their welfare.

\section{Divestitures}

Most hostile takeovers are followed by significant divestitures: sales of divisions of the target companies to other firms, investment companies, or management teams in MBOs. Unlike layoffs, debt increases, or investment cuts, divestitures do not necessarily imply operational or financial changes, although such changes may be made by the acquirers of divisions following the divestitures. We do not identify these changes since we cannot follow what happens to the acquired businesses. However, it is useful to describe the extent of divestitures and to note how they should be interpreted.

Bidding firms might sell off divisions of the target firms simply to pay off some of the debt incurred in the acquisition. Such a move, however, does not explain how divestitures fit into the bidders' plans to justify the premium. For if the target was valued fairly before the takeover, and if the buyers of divisions pay fair prices for them and do not make any changes in the operations, then divestitures do nothing to explain the takeover premium. This section suggests several ways in which divestitures help pay the premium. 
First, the target might have been underpriced in the stock market to begin with, and so if a bustup occurs at fair market prices, takeover organizers can profit by unbundling undervalued divisions. This theory of divestitures based on undervaluation of conglomerates has been tested by Dean LeBaron and Lawrence Speidell. ${ }^{18}$ They compute breakup values of conglomerates by applying price-earnings multiples of undiversified firms in the same industry as each division of the conglomerate to the earnings of that division and adding up the divisions. They find that this breakup value of conglomerates is typically higher than the market price. They do not take into account the possibility that divisions of conglomerates might be getting lower multiples because they grow less fast or invest in projects with negative net present value. Nonetheless, their analysis is suggestive.

Second, if the diversified company sold for a fair market value under its old management, it must be that the pieces are worth more to the buyers than they are to the takeover artist or under the old management. One such group of buyers, incentive-intensive organizations such as management buyout teams or investment companies, can improve the cash flow by reducing tax payments, cutting investment and employment, and taking other steps to reduce costs. In these cases, the higher cash flow comes from more effective management and not from combining two related firms. To be sure, we still cannot conclude in these cases that the primary source of value gains is efficiency improvements rather than wealth transfers.

A second type of buyer to whom divisions of a target firm could be especially valuable is a strategic buyer with his own operating company who can either exploit the combination of the two firms or is simply willing to overpay for the division. Such strategic buyers are in fact much more common than divisional MBOs, and selloffs to them are probably the main reason that bustups are profitable. Just as with initial acquisitions by strategic buyers, it is not known whether these selloffs to strategic buyers improve efficiency or just redistribute wealth away from consumers, suppliers, or other firms in the industry.

\section{Tax Savings}

Reductions in taxes can come from a variety of sources, the first and most obvious of which is the savings from merging a profitable company

18. LeBaron and Speidell (1987). 
with one that has tax losses. The combination can realize the tax benefits sooner than the owner of tax losses can alone, and therefore these benefits are more valuable to the combined entity. Alan Auerbach and David Reishus have shown, and we confirm with our data, that these tax benefits are important in some 5 percent of the cases. ${ }^{19}$

The second source of tax savings before the 1986 tax reform was the general utilities doctrine combined with accelerated depreciation, which enabled the acquirer to redepreciate the target's assets in some cases without the selling company's having to pay capital gains taxes on the assets sold. Unfortunately, no available studies gauge the magnitude of this source of tax savings.

The third source of tax savings has been conversion of the target, or some part of it, into a partnership, such as a master limited partnership. As a result, double taxation of profits - at both the corporate and the individual level-could be avoided. This loophole is largely closed now, but was available during our sample period.

Perhaps the most important potential source of tax gains in takeovers is increases in leverage and deductibility of interest payments on debt. These gains can be achieved if the target was underleveraged to begin with, so that increases in leverage create corporate-level tax benefits not offset by significantly higher expected costs of financial distress or personal taxes paid by bondholders. In the case of leveraged buyouts, Steven Kaplan shows that tax savings from leverage explain at least 50 percent and perhaps more than 100 percent of the takeover premium on average ${ }^{20}$ This number makes all the other sources of gains pale by comparison. To estimate the value of the tax shield, we would need information on how fast the debt is repaid. Our rough estimates suggest that the potential for increasing value through higher leverage in hostile takeovers is indeed substantial but still much smaller than Kaplan's estimate for the MBOs.

\section{Investment Cuts}

Jensen argues that takeovers stop target firms from investing their surplus cash in negative net present value projects. ${ }^{21}$ The takeover gains

19. Auerbach and Reishus (1988).

20. Kaplan (1989).

21. Jensen (1986). 
are realized because the money previously wasted is now distributed as interest or dividends. Jensen cites oil exploration expenses and diversification by conglomerates as examples of wasteful expenditures. Part of the gain in a takeover, then, is a commitment to stop such investments.

Inferring waste from post-takeover investment cuts is not as simple as it looks. First, cuts in investment can simply be a response to low availability of internal funds rather than a source of value. Kaplan finds evidence of significant investment cuts in management buyouts, but it is not clear whether these cuts eliminate waste or productive investment. ${ }^{22}$ Second, the divestitures and fast debt repayment that typically follow hostile takeovers relax the cash constraint and therefore might actually make further wasteful investment easier even in Jensen's model. His model does not explain why firms try to get back so quickly to the level of cash flow at which they can invest. Despite these reservations, Jensen's free cash flow theory is a tenable explanation of hostile takeovers in several industries, and we try to evaluate its empirical relevance.

\section{Summary}

These potential sources of target shareholders' wealth gains in takeovers-bidding shareholders' losses, gains from strategic combinations, layoffs, divestitures, tax savings, and investment cuts-are germane to a variety of takeover theories. Unfortunately, one can rarely infer from the evidence about these operational changes whether takeover gains are dominated by efficiency improvements or by wealth transfers. Strategic takeovers probably increase operating efficiency but might hurt consumers, suppliers, or industry rivals as well. Layoffs both raise efficiency and transfer wealth from workers earning substantial rents at their jobs. Divestitures raise efficiency if firms are sold to better management teams, but they also reflect transfers as underpriced companies are busted up or as divisions are sold to overpaying growthoriented managers. In the latter case, efficiency might fall. Tax savings are largely transfers from the government; they are not efficiency gains. Finally, investment cuts can eliminate wasteful overinvestment, but 
they can also transfer wealth from the investment sector (for example, oil field services). Moreover, investment cuts necessitated by high leverage might actually decrease total wealth. The result is that many of the changes following hostile takeovers cannot be unambiguously interpreted as wealth transfers or efficiency improvements-they probably have elements of both. Nonetheless, the question remains of how important some of these changes are empirically.

\section{Description of the Data}

As noted, the sample in this paper consists of all 62 firms that were targets of hostile takeover offers of more than $\$ 50$ million, as reported by W. T. Grimm for the period $1984-86 .{ }^{23}$ Like most others, W. T. Grimm classifies hostile takeovers as those in which the target's board at least initially expressed opposition, if only to raise the price. The sample stops in 1986 to allow a look at changes in the two to three years following the takeover. The sample includes successful hostile takeovers, hostile takeover attempts in which the actual acquisition was completed by a "white knight" (including defensive MBOs), and unsuccessful hostile takeover bids in which the target remained independent. Whenever possible, we point out systematic differences between outcomes for targets that are successfully acquired by hostile bidders and outcomes for those that are ultimately acquired by white knights or remain independent. A substantial coercive element is probably present in almost all of these deals.

Table 1 presents the distribution of our sample of hostile takeover attempts, by outcome, during the three years of our sample. The number of attempts nearly tripled. The ratio of takeovers by white knights relative to straight hostile takeovers also rises substantially, perhaps because of the increased availability of investment resources on the part of large firms that usually act as white knights over the course of the economic expansion.

23. We used the $\$ 50$ million cutoff because too little information was available for smaller deals. This restriction eliminates few observations, since being a target of a hostile bid is typically a privilege of only very large firms with diffuse ownership structures. 
Table 1. Distribution of Sample of Hostile Takeover Attempts in the United States, 1984-86

\begin{tabular}{lccr}
\hline \multicolumn{1}{c}{ Outcome } & 1984 & 1985 & 1986 \\
\hline Successful takeover & 7 & 12 & 10 \\
White knight acquisition & 1 & 8 & 12 \\
Unsuccessful bid & 2 & 4 & 6 \\
Total & 10 & 24 & 28 \\
\hline
\end{tabular}

Source: Andrei F. Rhoads, ed., Mergerstat Review 1986 (Chicago: W. T. Grimm, 1986); and authors' calculations.

The most important constraint on the analysis of post-takeover experience is that the bidder and the target are merged. That is why Ravenscraft and Scherer's line-of-business sample is in many ways more informative than our own, although it comes from an earlier period and hence has few hostile takeovers. ${ }^{24}$ For the same reason, Kaplan can get much better information in some respects by focusing on MBOs. ${ }^{25}$ Our research is limited by our inability to separate the target and the bidder, and our reluctance to use the joint data.

Throughout the analysis, we rely on multiple sources of data, including the Center for Research and Security Prices (CRSP) stock price data; bidder and target annual reports; $10 \mathrm{~K}$ forms; Moody's Industrial Manual; Value Line Investment Survey; the Wall Street Journal; the New York Times; business periodicals, especially Business Week and trade publications; and DATEXT. We try to piece together the information from all these sources because post-takeover information typically concerns the merged firm, making the attribution of changes to the target difficult. Most important, for our analysis of layoffs, selloffs, investment cuts, and tax savings we use only quantitative information. Our numbers should not be confused with journalistic opinions. Because reporting can be incomplete, however, most of our measures of changes are probably biased downward. We measure only what is reported. In interpreting our results, it is crucial to keep in mind these data limitations.

24. Ravenscraft and Scherer (1987).

25. Kaplan (1990). 


\section{Wealth Changes of the Shareholders}

The first step in documenting the wealth changes of shareholders is to calculate the gain, or the premium, paid to the target firm's shareholders. ${ }^{26} \mathrm{We}$ compute the premium as follows. First, we take the (often long) period from 20 days before the first bid for the target is announced, to the day when the target accepts or defeats the final bid. We call the first date Date1 and the second Date2. We then estimate the market model for each target firm from 260 trading days before Date1 to 60 trading days before Date1. Using that market model, we forecast what the price of each target would be on Date2 given its actual value on Date 1 and the return on the market between Date1 and Date2. The premium is the difference between the price paid (or offered in the last bid in the case of unsuccessful takeovers) for the target and the predicted price on Date2. In other words, the premium is the difference between what was paid (offered) and what the price would have been on the resolution date had no takeover activity occurred. We use the long interval to take account of market movements during the period of negotiation. At the same time, we do not use any market prices, other than the price of 20 days before the very first bid, to compute the premium because market prices reflect a variety of market beliefs and hence do not reflect the premium alone. Using such prices generally leads to lower estimates of the premium than our procedure.

Computing changes in the wealth of the bidding firm's shareholders is more complicated because there is no equivalent of the price paid. Also, using a long interval in this case creates significant problems, because many large acquirers have dramatic value changes over long intervals that might have nothing to do with the acquisition. Accordingly, to evaluate the change in the wealth of the bidding shareholders, we define Date 3 as the date of the first bid by the actual acquirer. Date 3 always falls between Date1 and Date2, and it often coincides with one

26. By focusing on shareholders, we ignore other financial claimants such as bondholders. There is no systematic analysis of the returns to bondholders in hostile takeovers. The analyses of takeovers as a whole show that bondholders unprotected by covenants lose small amounts of wealth, whereas protected bondholders do not lose-see Asquith and Wizman (1989). The magnitude of bondholder wealth losses is quite small relative to shareholder wealth gains. 
of them. We then estimate the market model for the bidding firm from 260 days before to 60 days before Date 3 and use this model to compute the abnormal change in bidding shareholders' wealth from 3 days before to 3 days after Date3. We define the return to bidding shareholders as this abnormal wealth change.

We do not estimate bidding shareholders' returns in unsuccessful bids because we have found no satisfactory procedures. Accordingly, in these cases we ignore the bidding shareholders and try to explain the premium offered to the target shareholders in terms of changes implemented after the bid.

The results for the takeover premium and for the increase in the wealth of the bidding shareholders are presented in table 2 . Throughout this paper, we deal with dollar rather than percentage wealth changes since it is dollar values that we try to explain. The premiums in this sample vary significantly, and some of them are very small when adjusted for market movements. These are typically the cases of bids highly contested by the target's management where the bidder gained control in part by buying shares in the open market. In general, the premiums are somewhat smaller than those one would obtain without the market correction because the market rose during this period.

The results on bidders are often missing. We do not compute the returns to bidders in unsuccessful takeovers. Furthermore, many of the bidders are not listed on CRSP because they are foreign companies (Hanson Trust, Campeau, First City Financial) or private companies often owned by the raiders (Reliance Capital, Maxxam, James Goldsmith, Asher Edelman, and so forth) or leveraged buyout specialists. As a result of these omissions, we report changes in bidding shareholders' wealth in only 30 cases.

The results are similar to the usual findings for bidders, except we find that bidder returns are negative in more than half the cases. On average, the bidders lose $\$ 15$ million, a tiny fraction of the average acquisition price of $\$ 1.74$ billion (including debt). Unavailability of data might bias these results toward finding poorer performance by bidders, since raiders typically bid through private firms and their returns are more likely to be positive. Note, however, that Irwin Jacobs, in two acquisitions by Minstar, earned a negative market-corrected return in both cases.

Bidder returns are very negative in some related acquisitions, such 


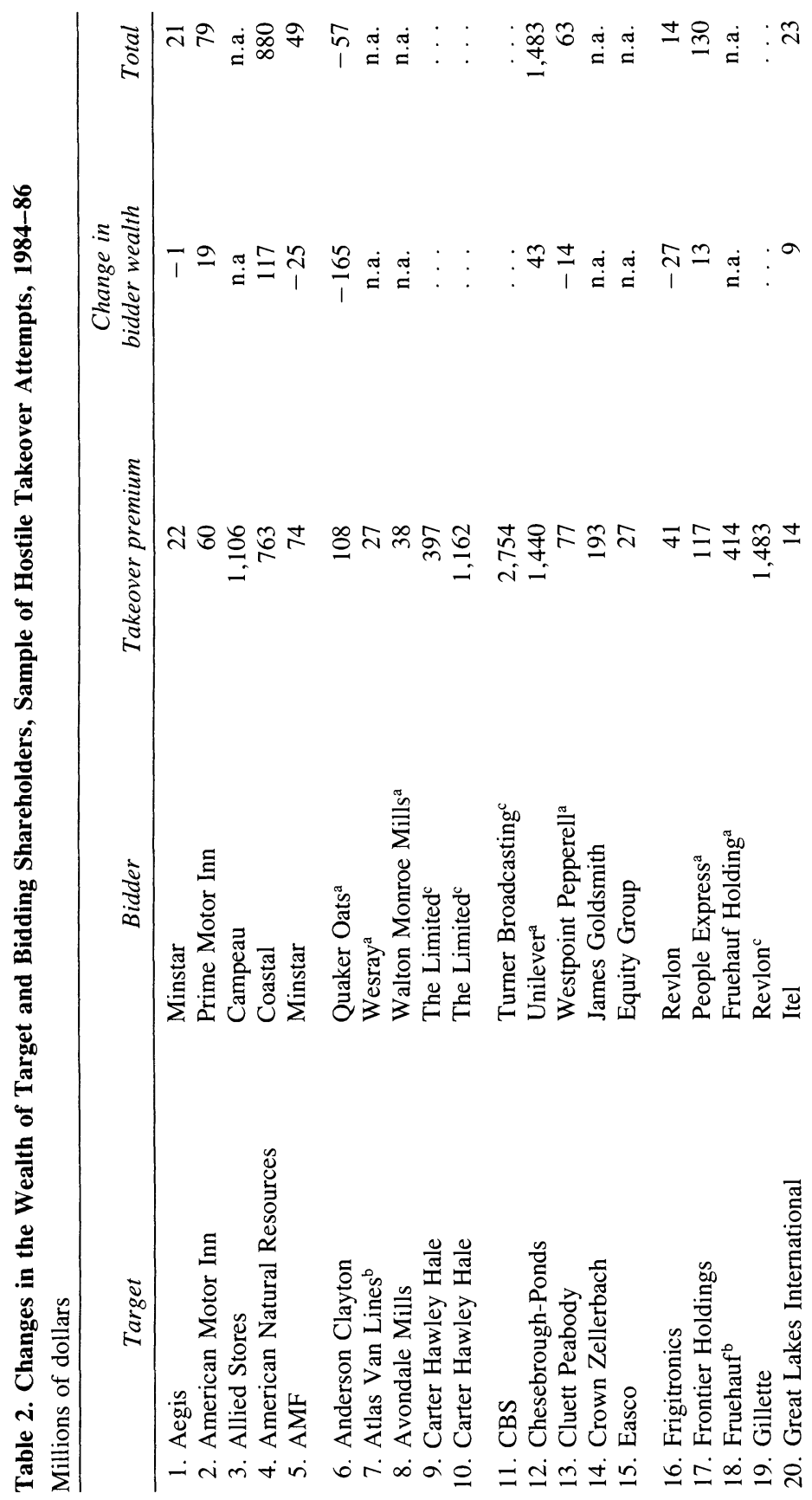




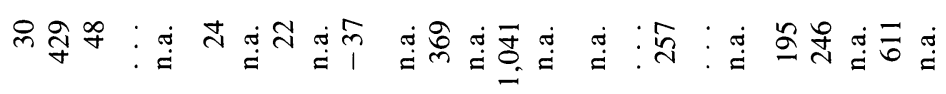

i =

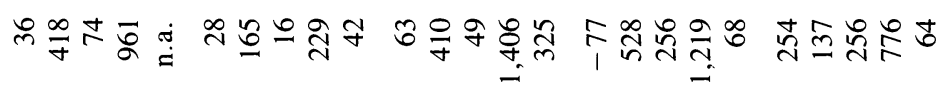

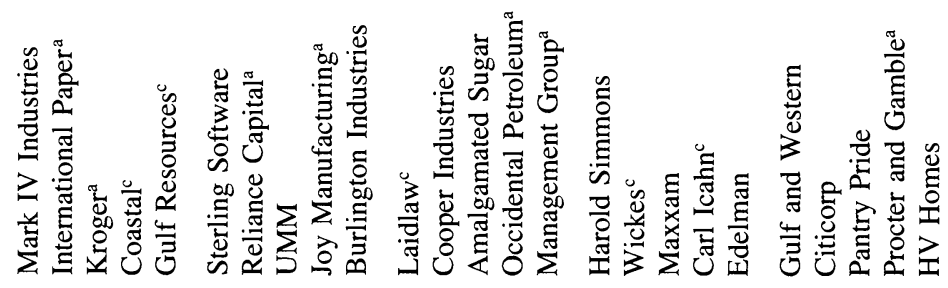

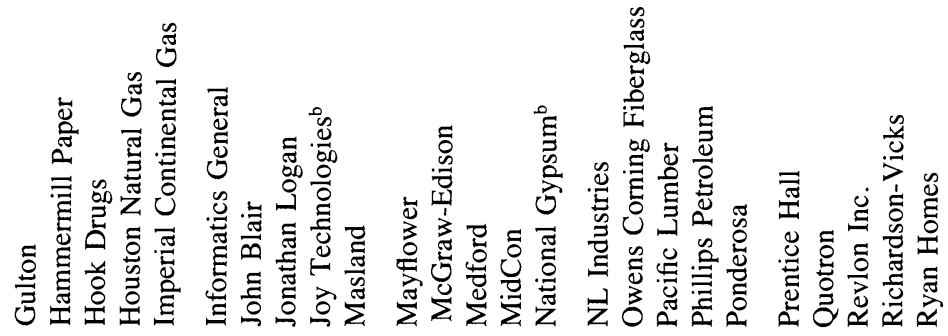

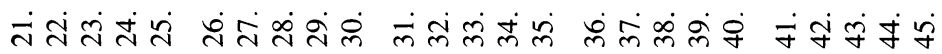




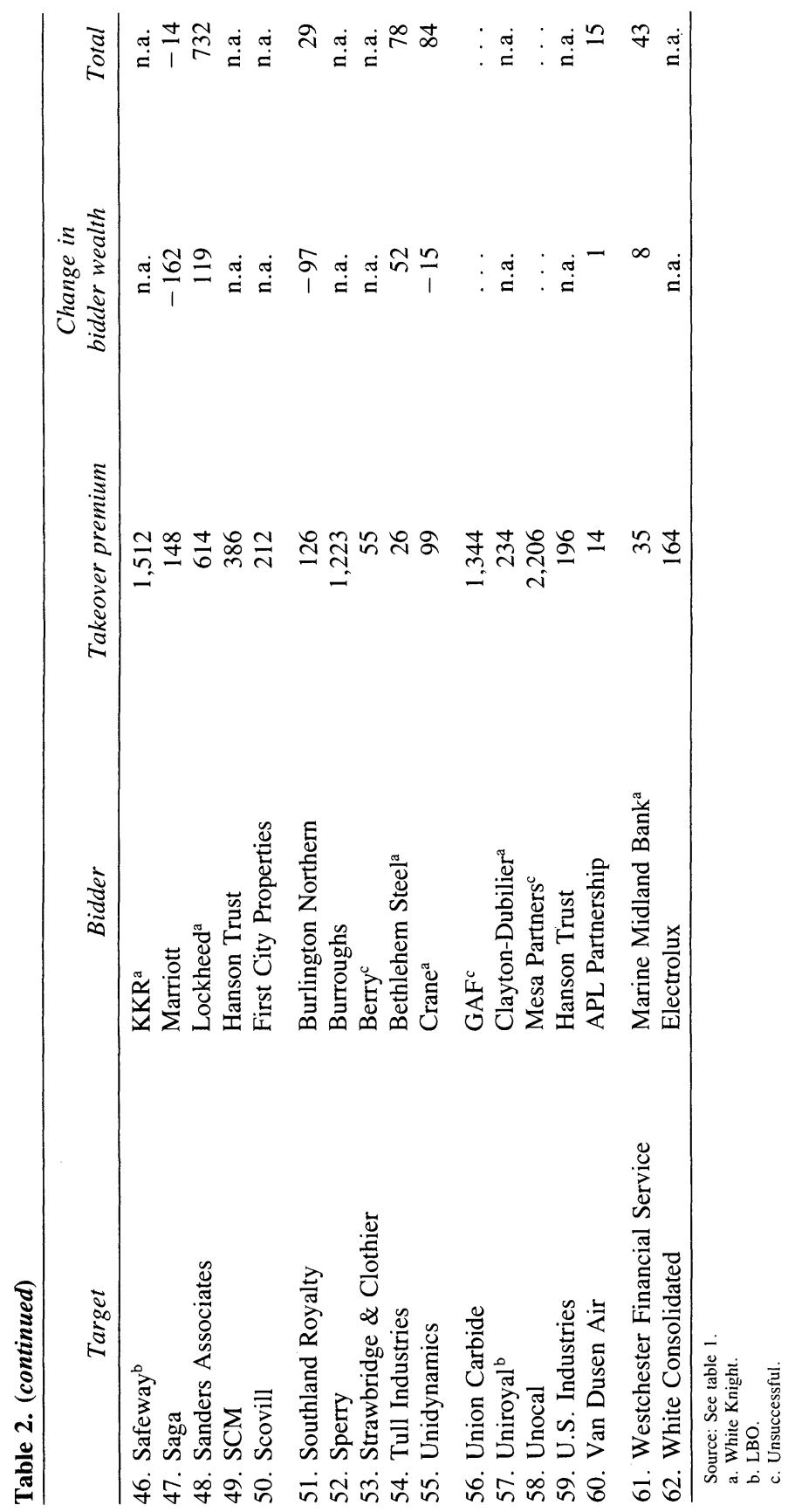


as Occidental's buying Midcon and Marriott's buying Saga. On the other hand, other strategic acquisitions, such as Citicorp's buying Quotron and Coastal's buying American Natural Resources, result in increases in the wealth of bidding shareholders. We cannot conclude from this sample that related acquisitions are systematically good or bad for the bidders, although earlier work by Morck, Shleifer, and Vishny suggests that in this period related acquisitions are better for the bidders than unrelated ones. ${ }^{27}$

The last column of table 2 presents the combined wealth change of the bidder and the target for the available observations. The change is positive in all but three cases, each of which is a strategic acquisition by a firm extending its product line. In general, most of the gains go to the target, and the bidder wealth change is relatively small, just as the other studies find. It is not the case in this sample that target gains can often be explained as bidder losses.

\section{Layoffs and the Takeover Premium}

One of the most direct ways for the acquirer to justify the takeover premium is to lay off employees and save on labor costs. The opportunities for layoffs are considerable: consolidation of headquarters, whitecollar employment cuts due to selloffs, closing of plants, consolidation of production, and many others. Because labor costs are so high relative to profits, the effect of such savings on the market value can be substantial.

Our measure of layoffs is the sum of layoffs and early retirements from the retained divisions that can be attributed to the target company, as reported by any of our sources. We use documented evidence of early retirements in only two cases (Gillette and Owens Corning); the vast majority of observations are layoffs. All types of layoffs are grouped together-those from plant closings, staff reductions, consolidations, and so forth. However, in most cases we can distinguish between whiteand blue-collar layoffs. Most of the information on layoffs comes from the Wall Street Journal, although other sources are sometimes used. In two cases, where we saw reports of layoffs but did not have the numbers,

27. Morck, Shleifer, and Vishny (1990). 
we called the bidding company and got the numbers from them. We include all post-takeover layoffs for three calendar years, starting with the year of the takeover.

For several reasons our post-takeover layoff numbers are biased downward. First, we do not include the layoffs from the bidding firm, although one could argue that these layoffs helped to pay the premium and hence can be included in the calculation of cost savings. Second, we look at actual layoffs and not at employment reductions due to selloffs. Nor do we follow sold-off divisions to check what happened to employment there. If the cuts occurred after the selloffs, we miss them. For these reasons, we do not use Compustat data on employment changes because bidder layoffs and especially selloffs are often the causes of reduced Compustat employment. Third, if no publication reported a layoff, we assume that none has occurred. Wherever we have data on both employment and layoffs, our layoff number is much smaller than the decline in measured employment, which reflects selloffs. Having mentioned these sources of downward bias in the layoff numbers, we should also mention that in some cases our numbers probably overestimate the number of layoffs precipitated by the takeover because the layoffs would have occurred anyway. More on this later.

To compute the value of labor cost savings, we assume that the aftertax cost of a blue-collar worker is $\$ 20,000$ a year, that of a white-collar worker $\$ 50,000$ a year. Labor costs of course include all benefits (including social security), which run at 30 percent or more of wages. These numbers imply an annual pretax labor cost of $\$ 30,000$ to $\$ 40,000$ for blue-collar workers and $\$ 70,000$ to $\$ 100,000$ for white-collar workers, depending on whether the tax rate is 34 percent or 46 percent.

The U.S. Department of Labor's publication, Employment and Earnings (January 1987), reports December 1986 weekly earnings for production workers in durable goods manufacturing of $\$ 443$, or approximately $\$ 23,000$ on an annual basis. A study by Felicia Nathan published in the Monthly Labor Review (October 1987) reports that wages are approximately 70 percent of total compensation in U.S. manufacturing. Using these figures, we get an average blue-collar pretax employment cost in durable manufacturing in 1986 of $\$ 32,600$. It is a little more difficult to get a handle on the employment cost for the average managerial worker laid off. Nathan's study reports that total compensation per hour for executive, administrative, and managerial workers is ap- 
proximately 1.8 times that for a typical blue-collar worker. We have assumed an employment cost for managerial workers 2.5 times that for blue-collar workers, adjusting Nathan's figure upward because the managerial layoffs in our sample are concentrated at corporate headquarters. In the few cases where we have both the number of laid-off workers and the annual cost saving reported by the firm, plugging in our estimates of labor savings gave us answers very close to the savings reported by the firms.

Of course, labor cost savings should be interpreted as the difference between the cost of hiring these workers and their marginal product. The laid-off workers might be producing only slightly less than they are paid, in which case the annual savings are much smaller. Unfortunately, we have no estimates of the marginal product and so cannot estimate the true savings. It is easier to believe that the marginal product of laid-off workers is lower for white-collar than for blue-collar workers, since white-collar functions of the target can be more easily carried out by the bidding firm without extra costs. We propose our calculation as a useful benchmark that should be adjusted on the basis of one's views about output loss.

The second question is how to compute the present value of labor cost savings. We assume that the real risk-adjusted discount rate applicable to this calculation is 10 percent, consistent with a real riskless rate of 4 percent and a risk premium of 6 percent. We use the real rate because in principle wages rise with inflation. We make the calculation assuming that the labor cost saving will last five years, after which perhaps the people would have been laid off or retired without replacement even without a control change. We also make the calculation assuming that the labor cost saving is permanent. To simplify the computations, we calculate the savings from layoffs on the assumption that all the layoffs are done right after the takeover. For both calculations of the present value, we also compute the ratio of the present value of labor cost savings to the takeover premium. The computation of the premium is described in the previous section. This gives us estimates of the fraction of the takeover premium that can be explained by labor cost savings.

The riskiness of savings created by layoffs is hard to determine. We would argue that the savings are risky in the sense that they might have been realized anyway if the firm did poorly but not if the firm did well. 
On the other hand, if the savings are closer to risk-free, perhaps a 5 percent discount rate might be appropriate. Use of a 5 percent discount rate would increase the five-year saving by only about 14 percent but would double the savings calculated as a perpetuity.

Table 3 presents the information on the 28 of our 62 firms for which there is direct evidence of layoffs. Recall that the sample includes successful hostile takeovers, white knight acquisitions, and unsuccessful takeovers. For the remaining firms, there is no evidence of layoffs. This is not necessarily to say that no layoffs occurred, but rather that the sources we have do not mention layoffs. For 7 of our 28 firms, the sources mentioned that layoffs had occurred but did not specify the numbers. Imperial Continental Gas was excluded from this analysis because it is foreign, and very little information on it is available. The averages are thus computed using 21 firms with layoffs and 33 firms for which no layoffs are mentioned and hence are assumed to be zero.

For the 21 targets that experienced layoffs, the number laid off ranges between 120 and 6,148 , or between 0.1 percent and 24.3 percent of the labor force of the target firm. The average layoff among the firms is 1,262 employees, or 5.7 percent of the firms' work force. These numbers, of course, are cut by about 61 percent to take account of the fact that 33 of the 62 firms experienced no layoffs. Even so, layoffs are not trivial for affected firms: a takeover-successful or not-costs on average 500 jobs, assuming that these people would not have been laid off had the takeover not occurred. At the same time, the total job loss in the economy because of companies directly affected by hostile takeovers is trivial. In our whole sample over three years, fewer than 30,000 workers were laid off.

Some evidence on the question of how much of the premium these layoffs can justify is also presented in table 3 . Under our assumptions about wages of white-collar and blue-collar workers, the annual aftertax labor cost savings range from $\$ 6.0$ million to $\$ 200$ million, with an average of $\$ 37.5$ million. If these savings last five years, they explain an average of 27.1 percent of the premium in cases where layoffs actually occur, with the range between 2.1 percent and 89.9 percent. In 9 out of the 21 cases these savings explain over a quarter of the premium. If these savings are permanent, they can justify 65.5 percent of the premium on average and more than a quarter of the premium in 15 out of 21 cases. Moreover, in 6 cases the savings can justify more 


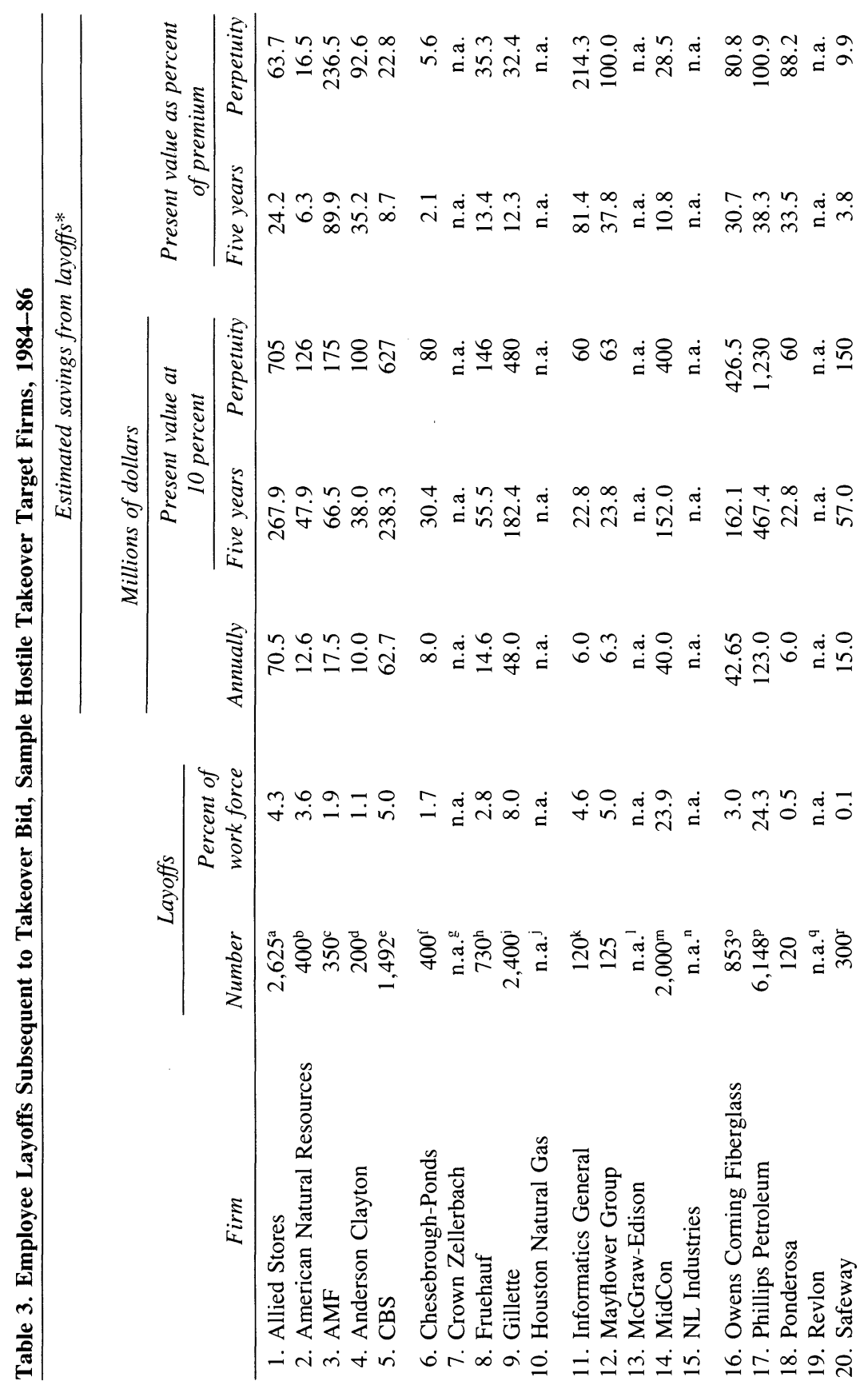




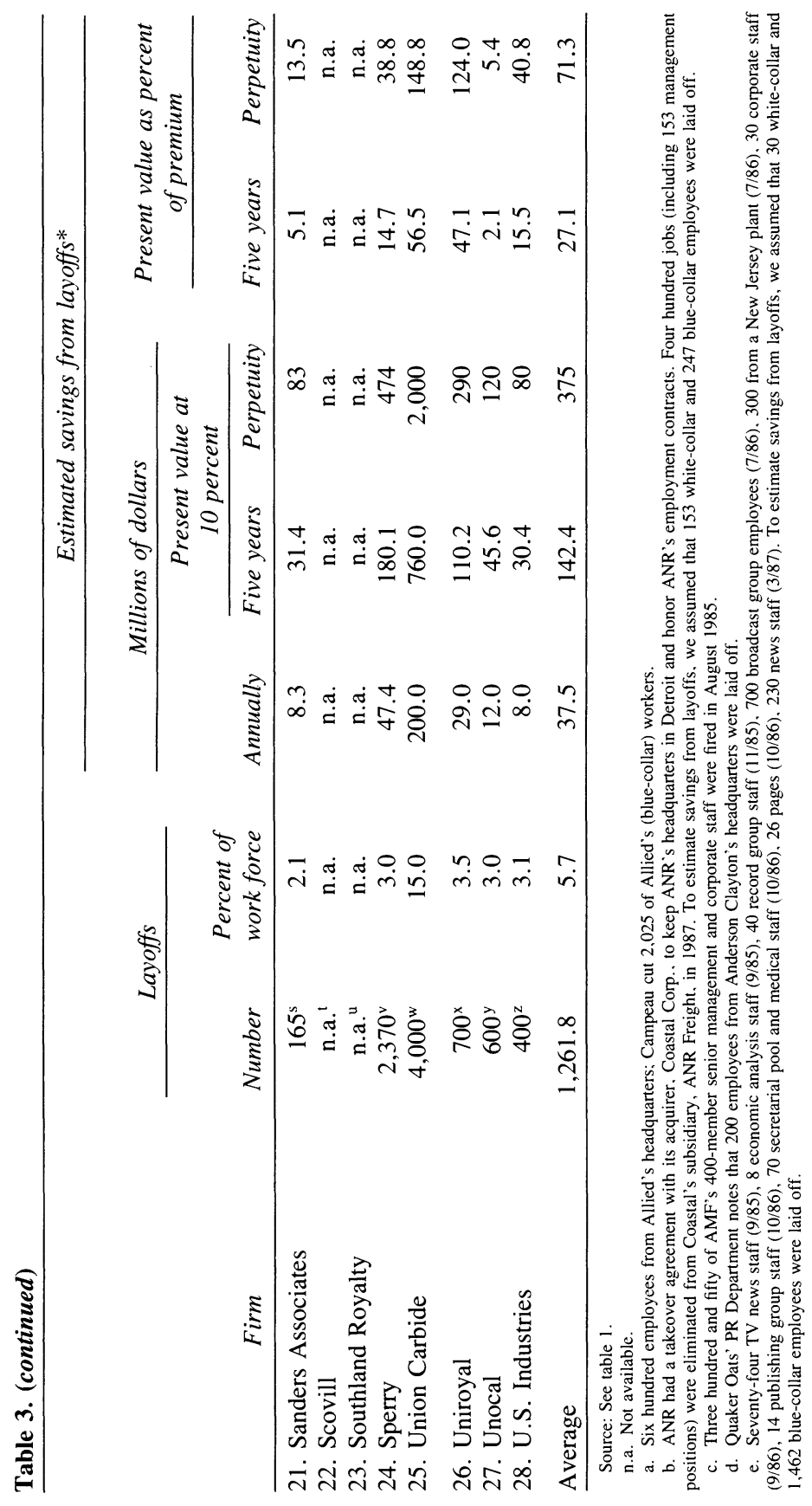




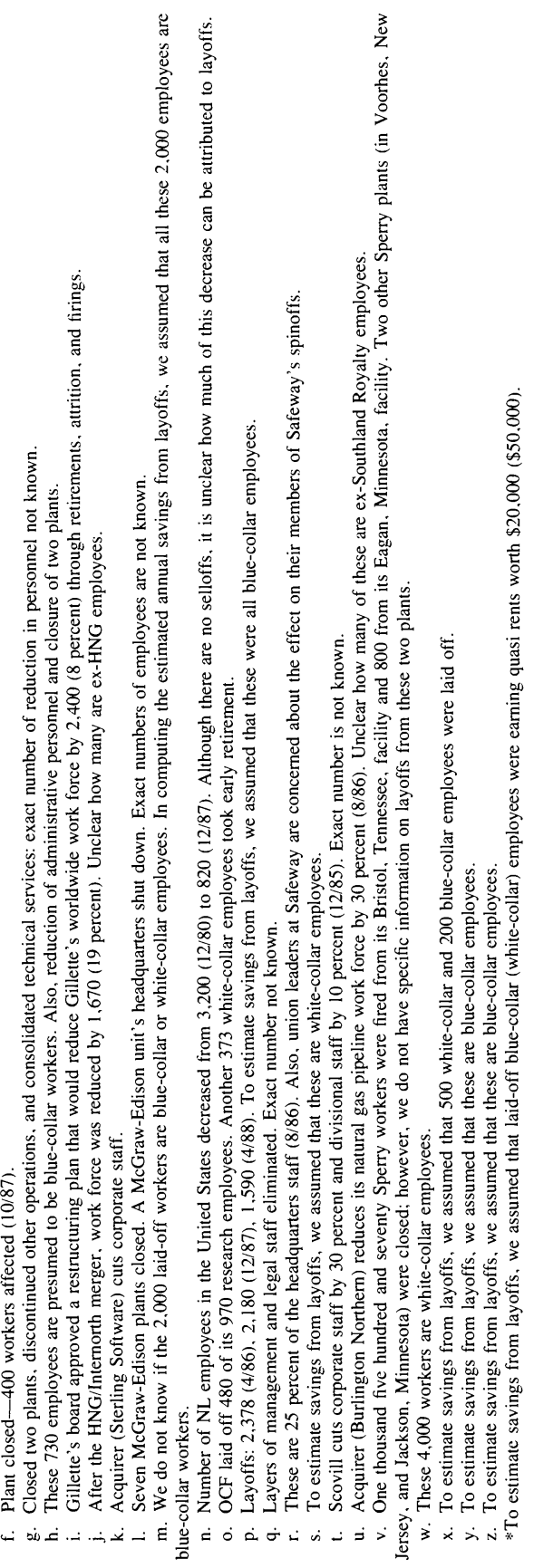


than the whole premium. Although the means should be cut by about 61 percent for the sample of all takeovers because in 33 cases there is no evidence of layoffs, the five-year labor cost savings can explain about 11 percent of the premium in an average takeover and permanent labor cost savings can explain perhaps 26 percent. With a 5 percent rather than a 10 percent discount rate, these numbers would be 12.5 percent and 52 percent, respectively. On the other hand, if the marginal product of laid-off workers is one-half of their wage rather than zero, the savings should be cut in half. Labor cost savings are thus only a moderate source of takeover gains.

In table 3 white- and blue-collar workers are grouped together. They are separated in tables 4 and 5 . For 13 companies out of 21 we can identify white-collar layoffs, and for 12 out of 21 we can identify bluecollar layoffs. In cases where we could identify them, blue-collar layoffs average 1,493 workers, or 6.5 percent of the firm's total work force, and save an average of 11.1 percent of the premium using a five-year horizon and 29.2 percent if the gains are permanent. Among the 12 firms for which we have numbers, white-collar layoffs average 660 employees, or 3.2 percent of the firm's total work force, which can justify 33.6 percent of the premium on average using a five-year horizon and 88.3 percent using a perpetuity. Since white-collar wages are assumed to be higher than blue-collar wages, the estimated savings from white-collar layoffs are higher than those from blue-collar layoffs even though the layoffs themselves are smaller.

White-collar layoffs are smaller in number and as a percentage of the total labor force than blue-collar layoffs, but of course the whitecollar labor force is on average much smaller than the blue-collar labor force of a firm. Virtually all laid-off white-collar workers in our sample are managerial and professional, a group that constitutes 25 percent of U.S. manufacturing employment, compared with 61 percent for production workers and 14 percent for clerical and sales. If we assume that our sample firms have a similar occupational structure, we can infer that the probability of layoff for white-collar workers is about 20 percent higher than for blue-collar workers. ${ }^{28}$ Because we have several outliers, it might be better to look at median layoff numbers that are

28. That is, $0.2=(0.61 / 0.25)(3.2 / 6.5)-1$. 


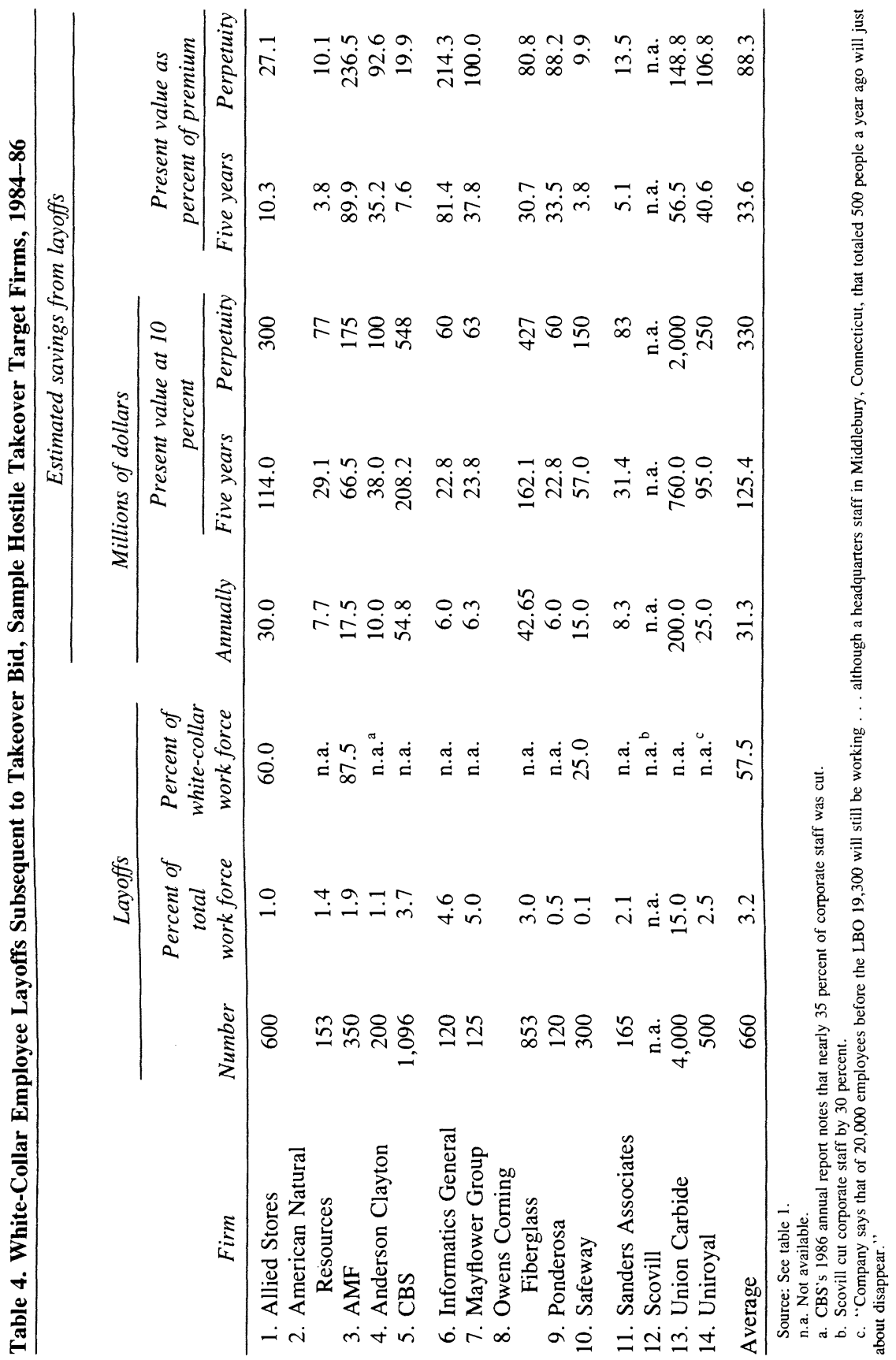




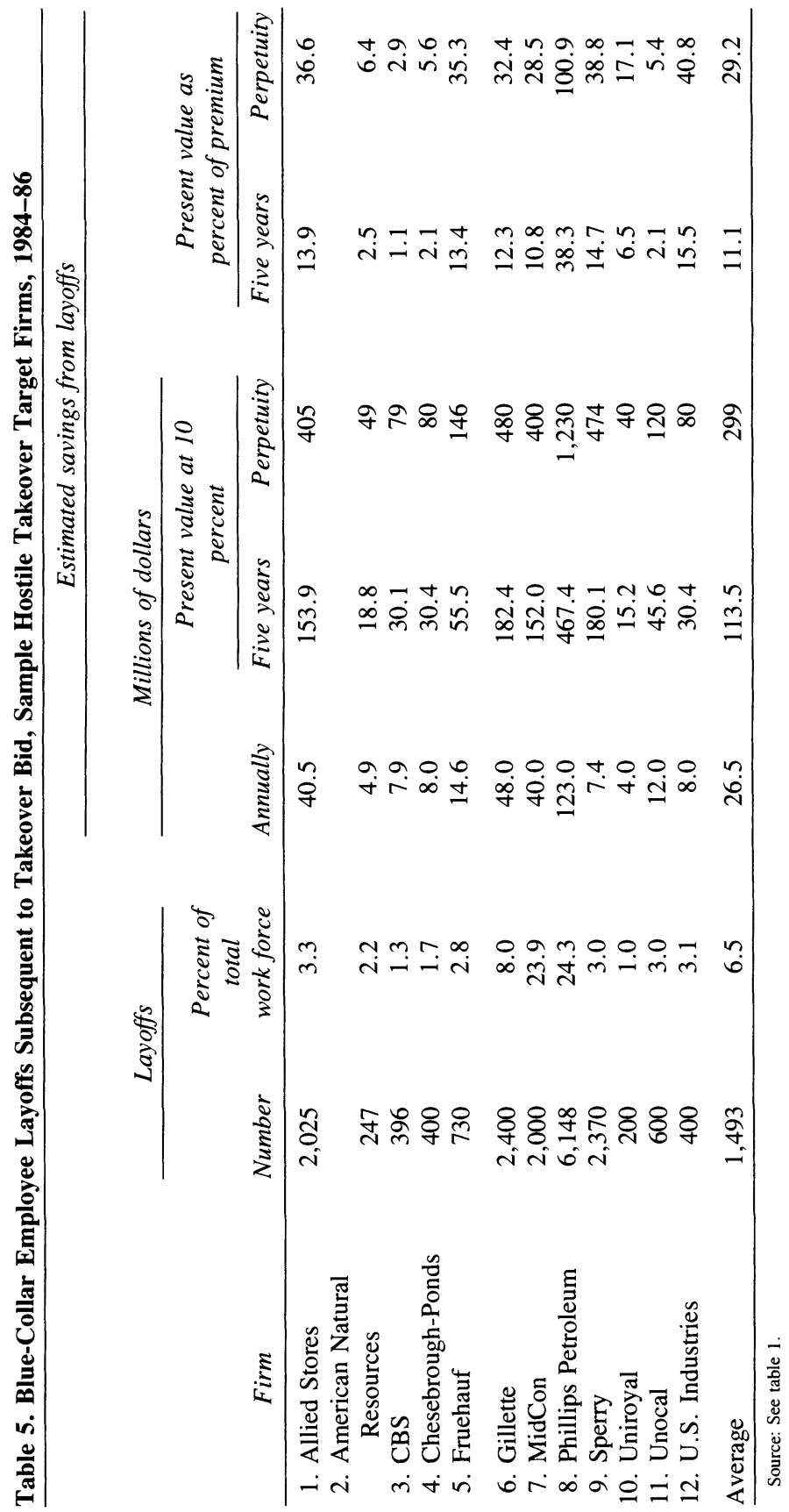


2.1 percent of the labor force for white-collar workers and 3 percent for blue-collar workers. These medians imply that the probability of a layoff is 70 percent higher for white-collar workers. ${ }^{29}$ In fact, since most of the laid-off workers are corporate staff, and these workers are an even smaller fraction of the labor force, the odds of a layoff of a corporate staff member are considerably higher than for any other class of worker.

The most common reason for white-collar layoffs is consolidation of headquarters after a takeover. In some cases, however, such as those of CBS and Union Carbide, white-collar layoffs are a large source of cost savings after unsuccessful takeover attempts. Blue-collar layoffs, in contrast, typically have to do with major retrenchments, as in the case of Phillips Petroleum. In some cases, such as that of Fruehauf, plant closings also lead to blue-collar layoffs.

Table 6 compares layoffs in successful, unsuccessful, and white knight takeovers. We discuss first the results for a subsample in which layoffs actually occurred and then the unconditional results for the whole sample.

Of the 21 target firms for which we could quantify layoffs, 7 were successfully taken over, 7 were acquired by white knights, and 7 remained independent. Both in terms of raw numbers and as a percentage of the labor force, firms that remain independent have the highest layoffs for blue- and white-collar employees combined. The fraction of the takeover premium that can be explained by savings from layoffs is highest for targets of successful takeovers-37.9 percent, compared with 16.8 percent for firms acquired by white knights, and 26.6 percent for firms that remained independent. The much higher fraction of the premium accounted for by layoffs after successful takeovers is some evidence in favor of breach of trust, as argued by Shleifer and Summers

In the table 6 subsample in which blue- and white-collar layoffs are separated, we again find that white-collar layoffs are most significant as a fraction of the labor force in targets that remained independent, but that savings from such layoffs are largest among targets of successful takeovers. With blue-collar layoffs, targets that remained independent again had the largest fraction of the labor force laid off, but the dif-

29. That is, $0.7=(0.61 / 0.25)(2.1 / 3.0)-1$. 


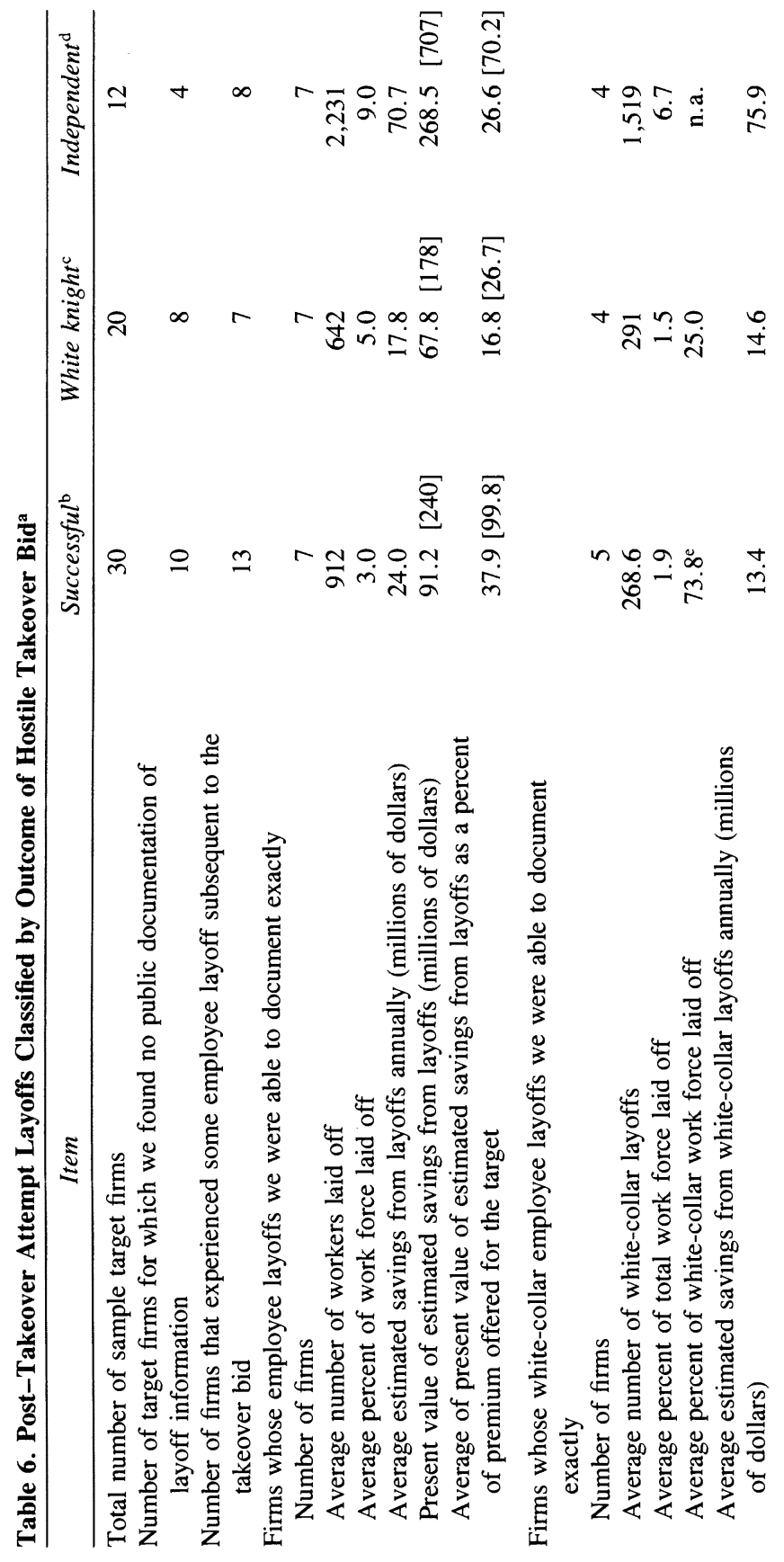




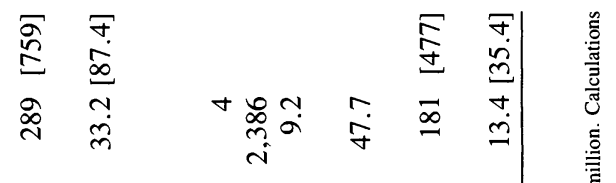

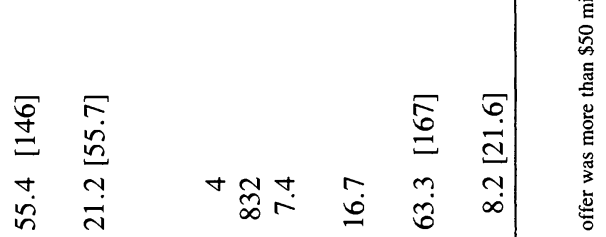

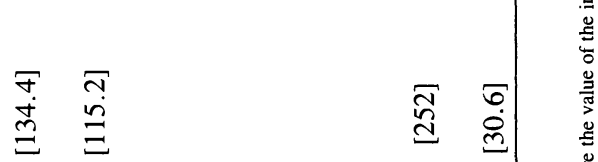

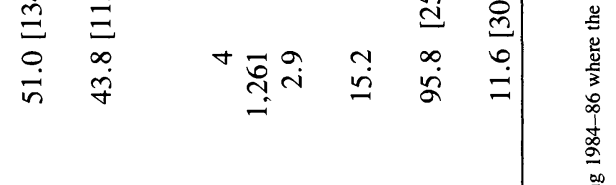

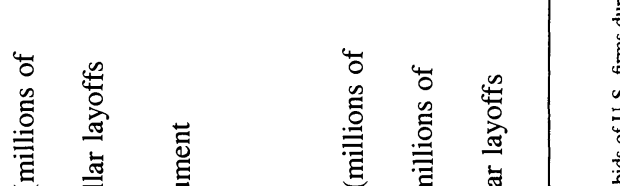

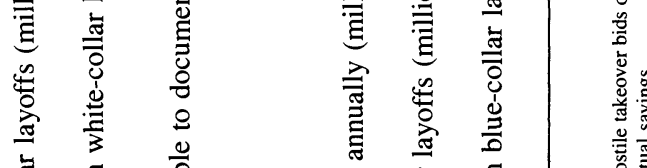

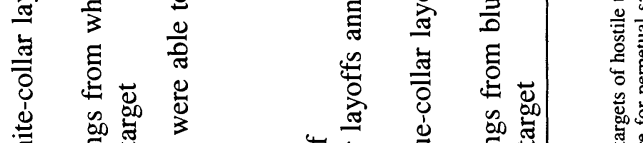

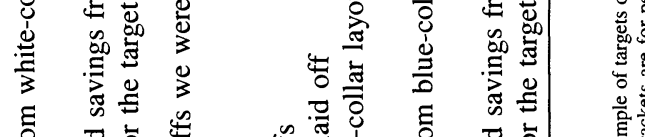

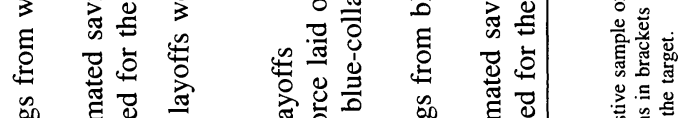

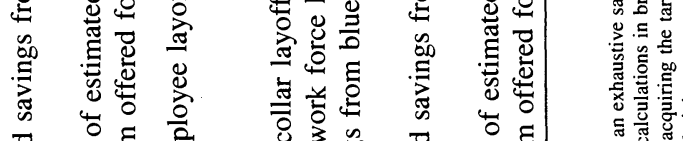

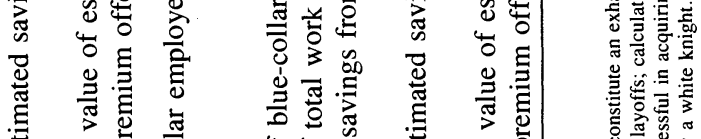

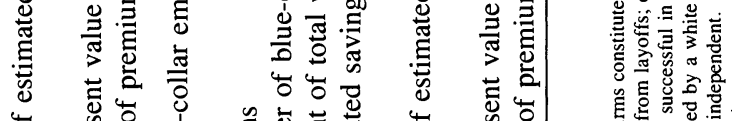

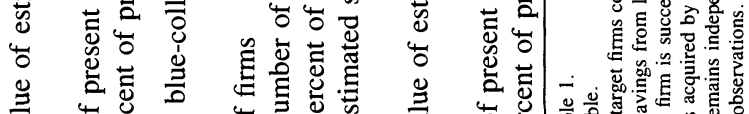

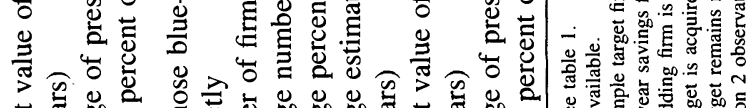

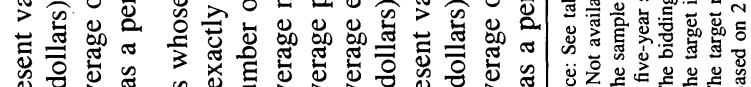

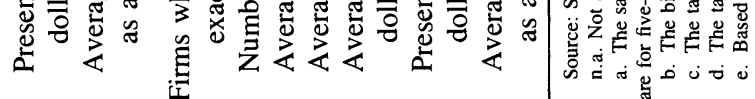


ferences in percentage of the premium accounted for by layoffs are no longer as large. These results provide mixed evidence for the breach of trust hypothesis. On the one hand, that white knights seem to make fewer layoffs than successful hostile acquirers, particularly when measured as a percentage of the premium saved, suggests that white knights breach fewer contracts than do the hostile acquirers. This is as predicted by the theory. On the other hand, we find that managers of firms that remain independent themselves lay off a lot of workers-both whiteand blue-collar. Perhaps targets that remain independent, unlike white knights, continue to be under pressure, which explains the greater layoffs.

One further nice piece of evidence illustrates the difference between successful acquirers and white knights. In the 30 instances of successful hostile takeovers, we have evidence of 10 closings or sales of headquarters; in the 20 instances of white knight acquisitions, we have no evidence of closings or sales of headquarters. If the sale of headquarters reflects breach of trust, this evidence shows clearly that hostile acquirers breach trust but that white knights do not.

The findings just described are for the subsample in which the layoffs actually occurred and can be measured. To understand the importance of layoffs in all takeovers, we must correct for the fact that in more than half the cases there is no evidence of layoffs. With the correction, the finding that targets that remain independent laid off most aggressively is strengthened. They laid off an average of 6.3 percent of the labor force, compared with 1.75 percent for white knights, and 0.9 percent for successful acquirers. The unconditional fraction of takeover premium explained by savings from layoffs is 18.6 percent for targets that remained independent, 5.9 percent for white knights, and 11 percent for successful acquirers. Thus the evidence on white knights as against successful acquirers is mixed, but the aggressive layoffs by targets that remained independent indicate that they continue to be under the pressure of takeovers.

An objection to this analysis of layoffs is that we do not compare post-takeover layoffs with pre-takeover layoffs in the same firms or with layoffs in other firms in the same industry. If layoffs reflect only industry trends, then takeovers cannot be responsible for them. But this argument is flawed. If fear of takeover is responsible for industry layoffs, then layoffs might well be the source of gains in acquired firms. 
Advocates of takeovers often credit takeover pressure for eliminating inefficient investment throughout the oil industry and not just in acquired firms. They do not give takeover pressure credit for industrywide employment reductions, but the logic is the same.

High costs of collecting data prevent us from conducting our analysis on the industries of acquired firms, but we made a few comparisons. First, we looked at the Wall Street Journal for evidence of layoffs for our 62 sample firms in the two years before the takeover attempt. The Wall Street Journal is not the only source of layoff information for our sample, but it is by far the dominant source. We have found evidence of layoffs in 8 firms before the takeover period, compared with 28 in the post-takeover period. Of these, 6 were firms that also had posttakeover layoffs. The average layoff was 275 employees, or 0.6 percent of the affected firm's employment. This translates into the unconditional average layoff of 35 employees, or less than 0.1 percent of the labor force, which is much smaller than the post-takeover unconditional average. Layoffs after the takeover are clearly greater than layoffs before. This evidence supports the idea that managers of hostile takeover targets are reluctant to breach implicit contracts unless thrown out or forced to do so under takeover pressure.

To examine industry layoffs, we matched each firm in the sample to a similar-sized firm in the same industry. We then used the Wall Street Journal to examine layoff practices of control firms over the same period as the sample firms. We have found that 11 control firms experienced layoffs during the relevant period, averaging 539 employees, or 5.2 percent of their work forces. The implied unconditional expected layoff for the whole control sample is 100 employees, or 0.5 percent of the work force-obviously much less than for the post-takeover sample. Although these results are biased down by the use of the Wall Street Journal only, layoffs in control firms measured in this way are very significantly smaller. The implication is that takeovers do cause layoffs.

In addition to layoffs, hostile takeovers often result in pension plan terminations accompanied by reversions of excess pension assets to the acquirer. Pontiff, Shleifer, and Weisbach document the increase in reversion activity after takeovers, and the greater frequency of such reversions following hostile takeovers ${ }^{30}$ In our sample, there is evi-

30. Pontiff, Shleifer, and Weisbach (1989). 
dence that 14 firms reverted pension plans after the takeover. Although in most cases these reversions are small, in a few, such as those of Union Carbide, NL Industries, and Jonathan Logan, reversions are a large fraction of the premium. Even if one takes the estimate of Pontiff, Shleifer, and Weisbach that only a third of the excess pension assets, on average, would have gone to the employees were it not for the reversion, one still gets nontrivial transfers in a few cases. This evidence confirms that pension reversions are common in hostile takeovers but rarely justify a large fraction of the premium.

In sum, layoffs after takeovers are common and can explain 10-20 percent of the premium. Moreover, layoffs seem to be much more common in our sample firms than in other firms in their industries. At the same time, layoffs are clearly not the whole story behind hostile takeovers, and it is hard to believe that plans for future layoffs constitute an important takeover motive. The direct consequences of takeovers for U.S. employment are trivial. Layoffs are a common by-product of the hostile takeover process but do not appear to be the driving force behind it.

\section{The Importance of Selloffs after Takeovers}

In this section, we compute the value of divestitures following hostile takeovers. As with layoffs, we look at all post-takeover divestitures during three calendar years starting from the year of the takeover. We followed the same strategy as with layoffs, making sure that the soldoff assets are from the target. When it proved impossible to attribute the divestiture to the target, we counted it as zero. This was the biggest problem when the target and the bidder are in the same industry and have relatively homogeneous assets, such as gas pipelines. The main sources of information on divestitures are Moody's and the Wall Street Journal, although annual reports and $10 \mathrm{Ks}$ also proved useful. In most cases we found prices of divestitures; otherwise, the divestiture is not counted. The restriction that divestitures must be identified with the target and have a reported price biases our count of divestitures downward.

In computing the total value of divestitures, we did not correct for market movements and simply added up the realized prices. This is an 
aggressive calculation during a period of rising stock prices, although it is not clear that a rising stock market always raises the value that a rational buyer is willing to pay for a division. We were conservative in taking the debt assumed by a buyer of a division to be zero, thus reducing the price that might have been effectively paid. Given these approximations, as well as the fact that some divestitures might have gone unreported, our estimates should be viewed as rough.

The results of this calculation, presented in table 7, reveal a significant number of selloffs in most takeovers. The average portion of the acquisition price realized through selloffs is 29.6 percent and the median is 16.6 percent. In only 20 cases out of 62 were there no quantifiable selloffs, and even in some of these cases, such as that of Aegis, there were selloffs, but we could not find the price. In 17 cases, more than half the acquisition price was regained through selloffs, and in 3 cases more than 100 percent was regained. It is absolutely clear from these data that selling off divisions is one of the most pervasive consequences of hostile takeovers.

\section{Who Makes Divestitures?}

There are a variety of selloff styles. Some cases are classic bustups in which the bidding firm does not seem to retain much of the target at all. Examples include Revlon's acquisition of Frigitronics and First City's acquisition of Scovill. Not surprisingly, such complete bustups are typically done by the raiders. We do not know whether the purpose is to take advantage of the underpricing of the target, to sell divisions to strategic buyers at inflated prices, to enable eventual acquirers to implement significant changes, or all three. Even in complete bustups, the takeover artist usually gets some benefits from headquarters layoffs.

Another, and perhaps more interesting, case of nearly complete bustups are acquisitions of conglomerates for the purposes of retaining some pieces of them. For example, when Quaker Oats bought Anderson Clayton, it retained the Gaines dog food business that it had previously sought and sold off everything else. Another example is James Goldsmith, which bought Crown Zellerback and sold off everything but the timber properties. A third example is Minstar, which bought AMF and Aegis and sold off most assets other than the boat divisions that it wanted. In these examples, the acquirer got the segment of the company 


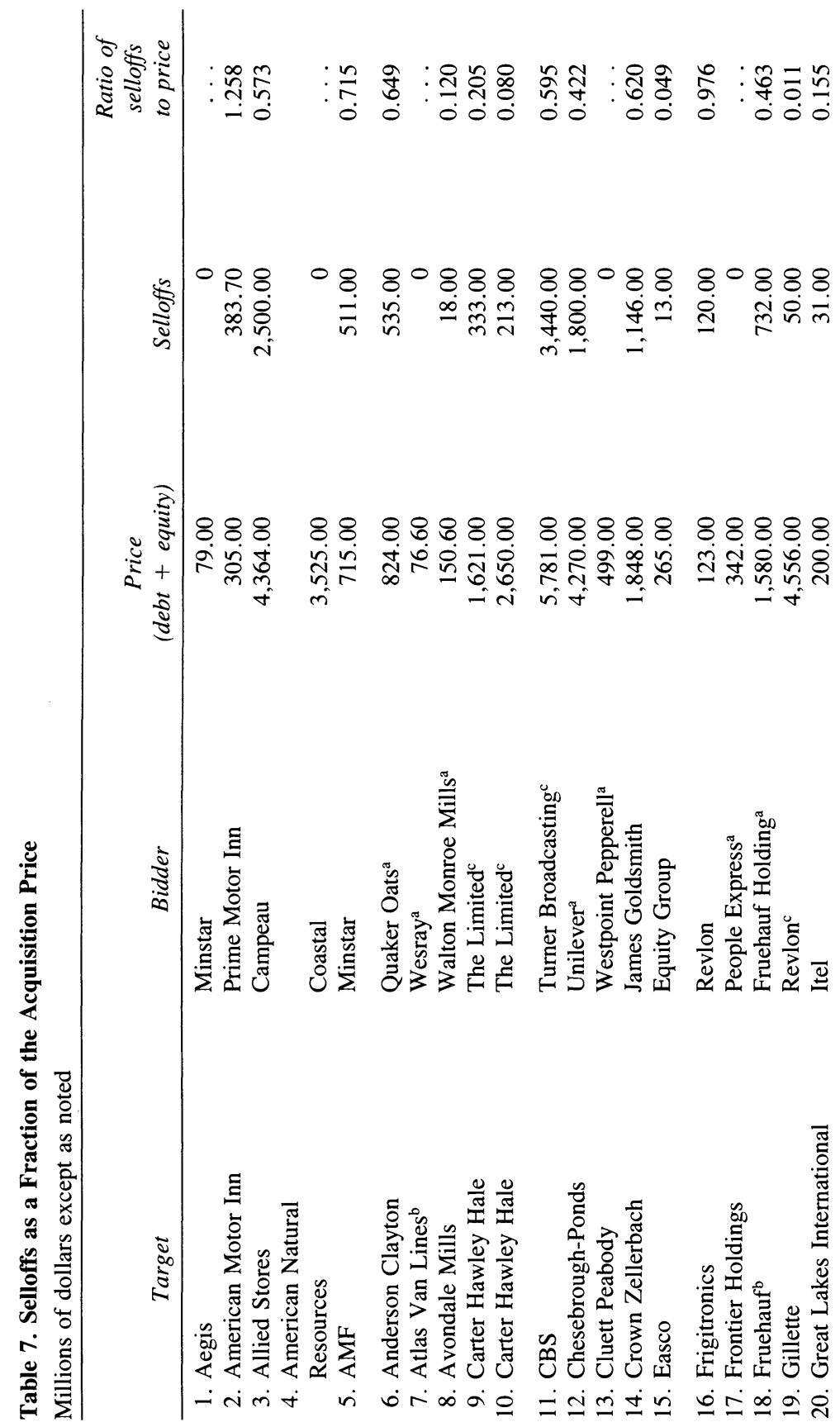




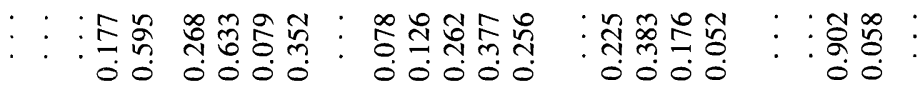

$$
\begin{aligned}
& 00088.888^{\circ} 88.88088 .80088^{\circ}
\end{aligned}
$$

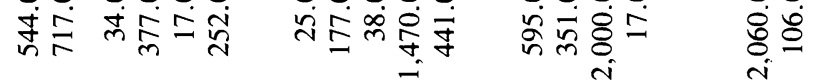

88888.888088888 .8888 .8888

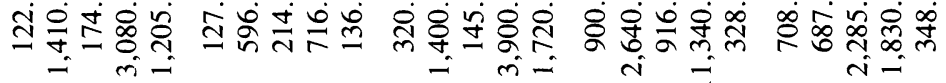
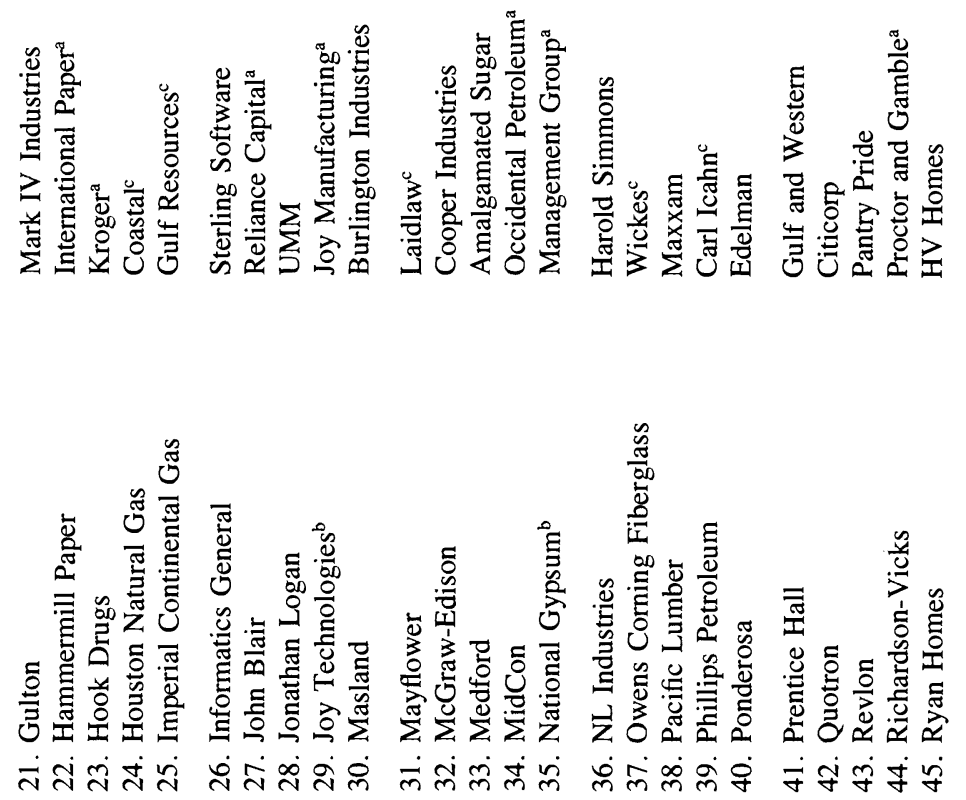


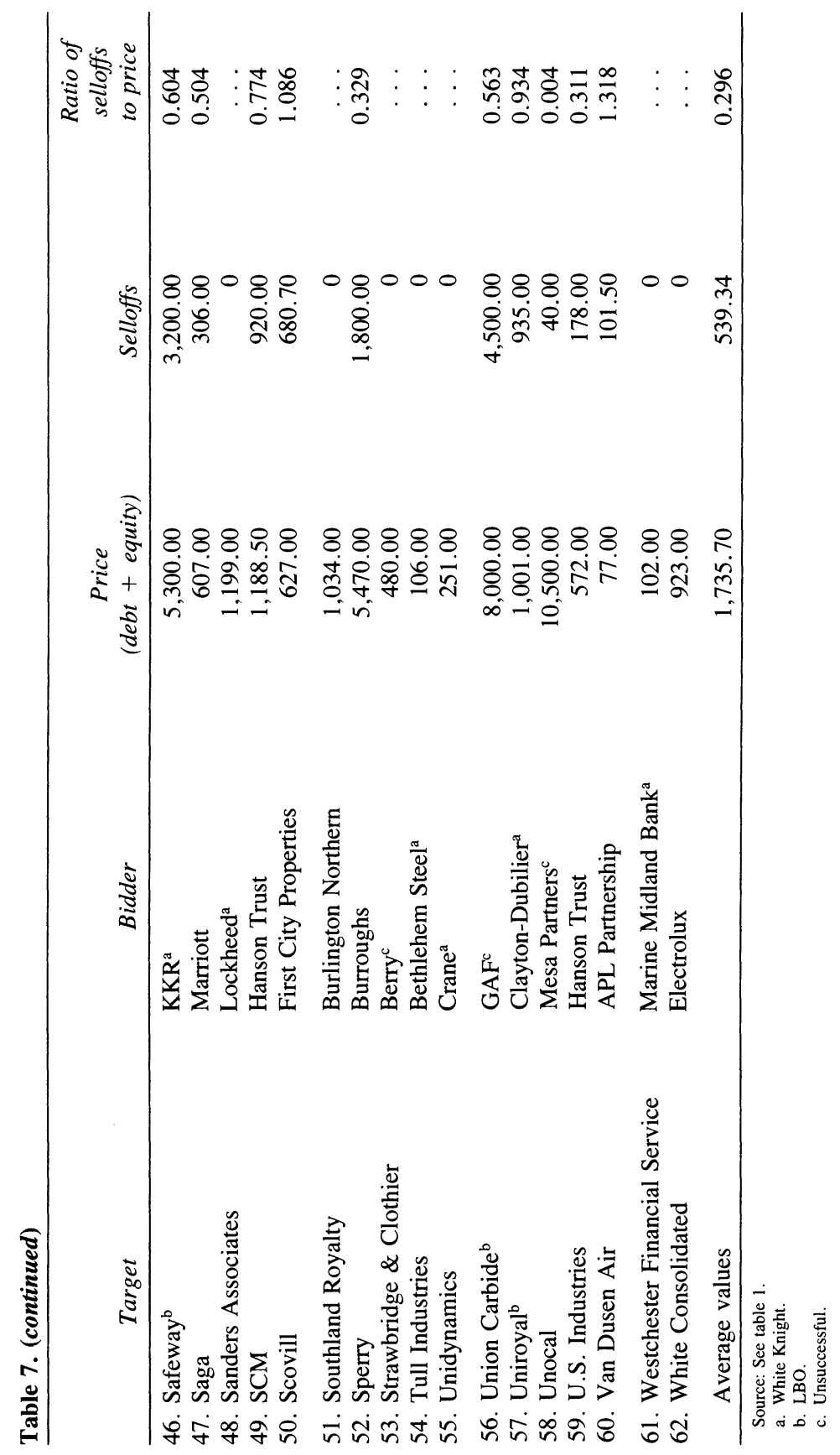


it wanted for an extremely low price and managed to get most of its money back through divestitures. These near-bustups suggest that even apparent bustup takeovers might be driven by the strategic objectives of the acquirers, with selloffs being an incidental consequence of the pursuit of particular businesses.

In about a third of the cases there are no selloffs at all, and in a few selloffs are minor. Examples of such low-selloff takeovers include Coastal acquiring American Natural Resources (both are pipelines), Walton Monroe Mills acquiring Avondale Mills (both are textile firms), Westpoint Pepperell acquiring Cluett Peabody (both are textile firms), Gulf and Western acquiring Prentice Hall (both are in publishing), and Citicorp acquiring Quotron (to pursue the alleged complementarity of banking and provision of stock quotations). As we argue later in the paper, such strategic acquisitions of whole or parts of companies are an extremely important part of the hostile takeover process. Without these wholly strategic bids, the average fraction of assets sold off after hostile takeovers would be even larger.

Several insights about the reasons for selloffs can be gained by looking at different types of transactions. When we compare LBOs with non-LBOs, we find that the mean portion of the acquisition price realized through selloffs in the two cases are 43.5 percent and 28.1 percent, respectively, and the medians are 40.7 percent and 12.3 percent. The incidence of selloffs is higher after LBOs, especially judging by the medians, which suggests that the pressure from debt is a reason for some selloffs. When we compare successful and unsuccessful takeovers, we do not find much difference in the fraction of the acquisition price recovered through selloffs. This finding suggests, as did our results on layoffs, that firms escaping the takeover often do most of the things that the acquirer would have done anyway. Finally, we do find fewer selloffs by white knights than by hostile acquirers. In the means, the portion is 24.3 percent for the former and 36.5 percent for the latter. In the medians, the ratio is 8.9 percent for white knights and 20.9 percent for hostile acquirers. The picture is similar to that with layoffs and headquarters closures: white knights do less than the hostile acquirers, but firms remaining independent have to make more changes than those acquired by a white knight. The explanation that targets remaining independent continue to be under pressure applies here as well. 


\section{Who Are the Buyers in Divestitures?}

Perhaps the most interesting question for understanding the function of divestitures is who the buyers are. If the function of hostile takeovers is to create organizations with appropriate incentives, such as high management ownership and high debt, then one would expect a lot of divestitures to MBO teams or to investment companies. If the function of hostile takeovers is to allocate businesses to strategic buyers, then one would expect most divestitures to be to strategic buyers. To examine these issues, we divide divestitures into those to strategic buyers (those in a business related to that of the acquired division), those to MBOs and investment companies, and those to unrelated acquirers. We also have two residual categories. The first is a small category consisting of headquarters buildings, stocks, and other liquid assets that are sold off. The second is the selloffs for which we cannot identify the buyer.

Table 8, which presents the results for each firm, shows that most selloffs go to acquirers in the same industry. The total volume of selloffs in this sample is $\$ 33.7$ billion. Of those, $\$ 23.70$ billion, or 70 percent, were selloffs of divisions to firms with lines of business the same as or closely related to those of the divisions. Compared with that, $\$ 5.4$ billion, or 16 percent, were sold off to MBOs or investment companies, and $\$ 2.8$ billion, or 8 percent, to unrelated acquirers. We could not identify the buyers in 4 percent of the sold-off assets, and 2 percent were headquarters and marketable assets selloffs.

Selloffs, clearly, go mainly to related acquirers. Such selloffs are four times more important than those to MBOs and other incentiveintensive arrangements. Even if we assume that all of the 4 percent of asset sales for which we could not identify the buyer are to an MBO or an investment company, we still get the result that selloffs to related buyers are three and one-half times more important.

These results present a different view of divestitures than that suggested by Jensen, who views the large incidence of divestitures as evidence that mergers do not increase concentration. ${ }^{31}$ Divestitures in fact seem to increase concentration (using industry-level measures employed by antitrust authorities), because the buyers of divisions are typically not the raiders or MBO boutiques but large firms in the same 


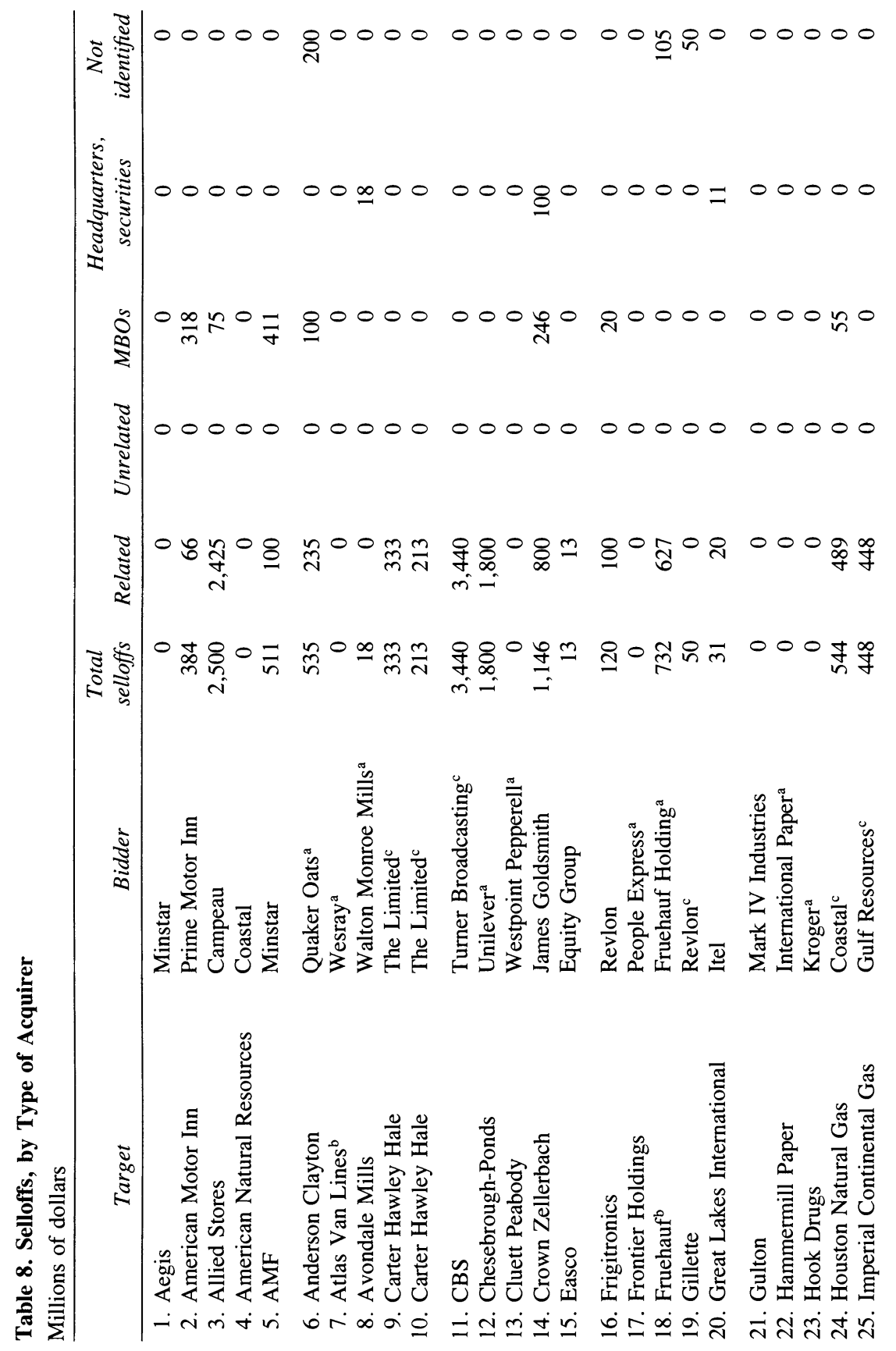




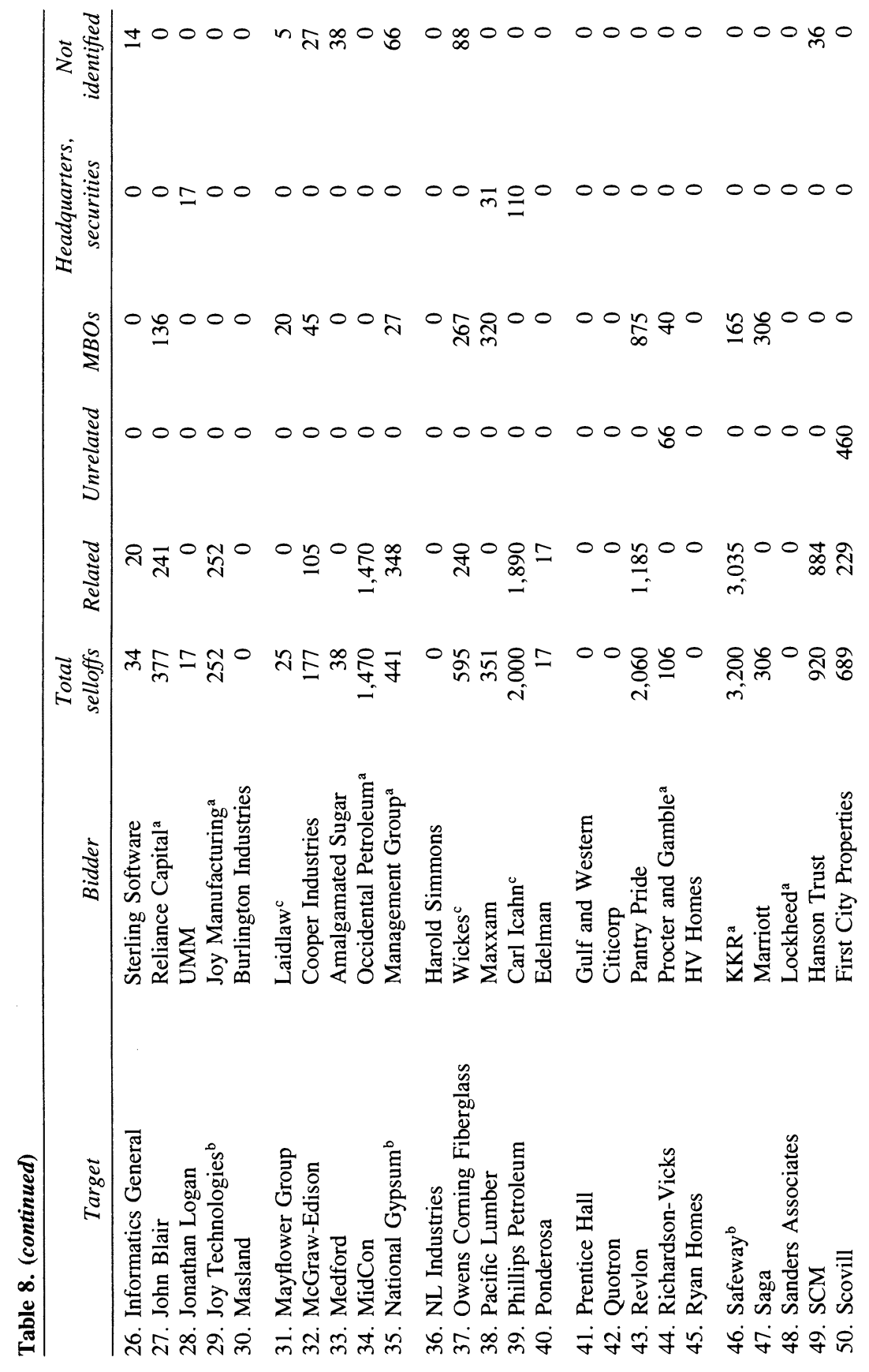




$$
\begin{aligned}
& 000008000000 \frac{2}{n} \\
& 00000 \text { 아잉 }
\end{aligned}
$$

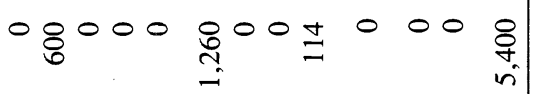

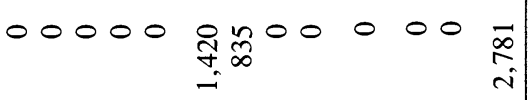

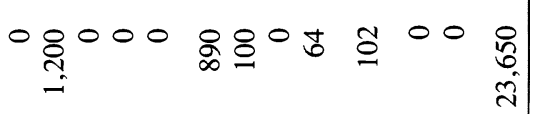

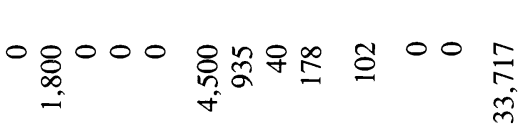

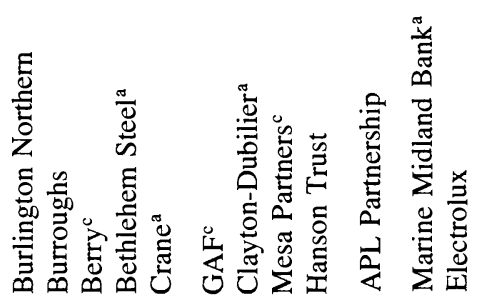

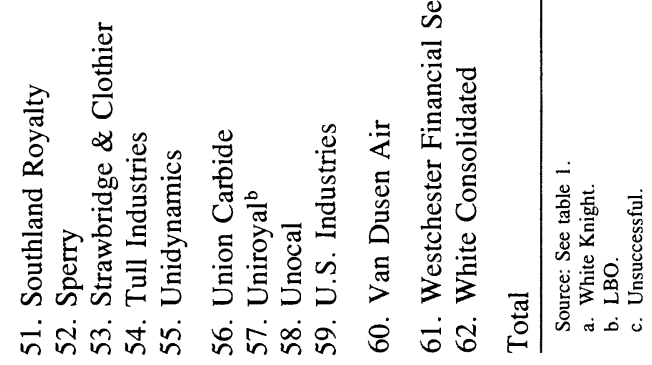


lines of business. In fact, the role of the raiders and MBO boutiques seems to be largely to take diversified firms, bust them up, and sell the divisions to other firms in the same business. Management buyout organizers and raiders thus serve as brokers working for the ultimate purpose of increased concentration. Their goal is to create a temporary organization that facilitates the allocation of assets to related buyers. Of course, debt and concentrated ownership create significant incentives for them to do a bustup. The evidence is clear that the goal of divestitures is typically to realize gains from industry consolidation, not to improve performance through an incentive-intensive organizational form.

\section{Analysis of Sources of Target Shareholders' Wealth Gains}

In table 9 we summarize the motives and the sources of gains that might have been important in each transaction. We look at the importance of strategic factors, selloffs, layoffs, tax savings, and investment cuts.

In three cases, we have not been able to find any clear sources of gain or takeover motives. The first is Revlon's bid for Gillette, which probably was intended to result in a bustup. However, Gillette did not make significant selloffs after defeating the bid, and its employment cuts, while large, could not have justified a large fraction of the proposed premium. As a result, we cannot clearly infer what Revlon was up to. The second case is Berry's unsuccessful bid for Strawbridge and Clothier, which was rapidly defeated by a controlling family and resulted in no changes. This observation is hard to fathom. Finally, we did not identify important sources of gains in Hanson Trust's acquisition of U.S. Industries. It is often said that operations are improved after Hanson's acquisitions, but we do not have adequate measures of that, and the measures we do have did not register significant changes.

\section{The Importance of Strategic Acquisitions}

Table 9 shows that 34 out of 62 acquisitions were strategically motivated. In most cases, the bidder was interested in the majority of assets of the target company. Such acquisitions thus reflect the same phenomenon that appears to underlie most friendly takeovers in the 1980s: firms 


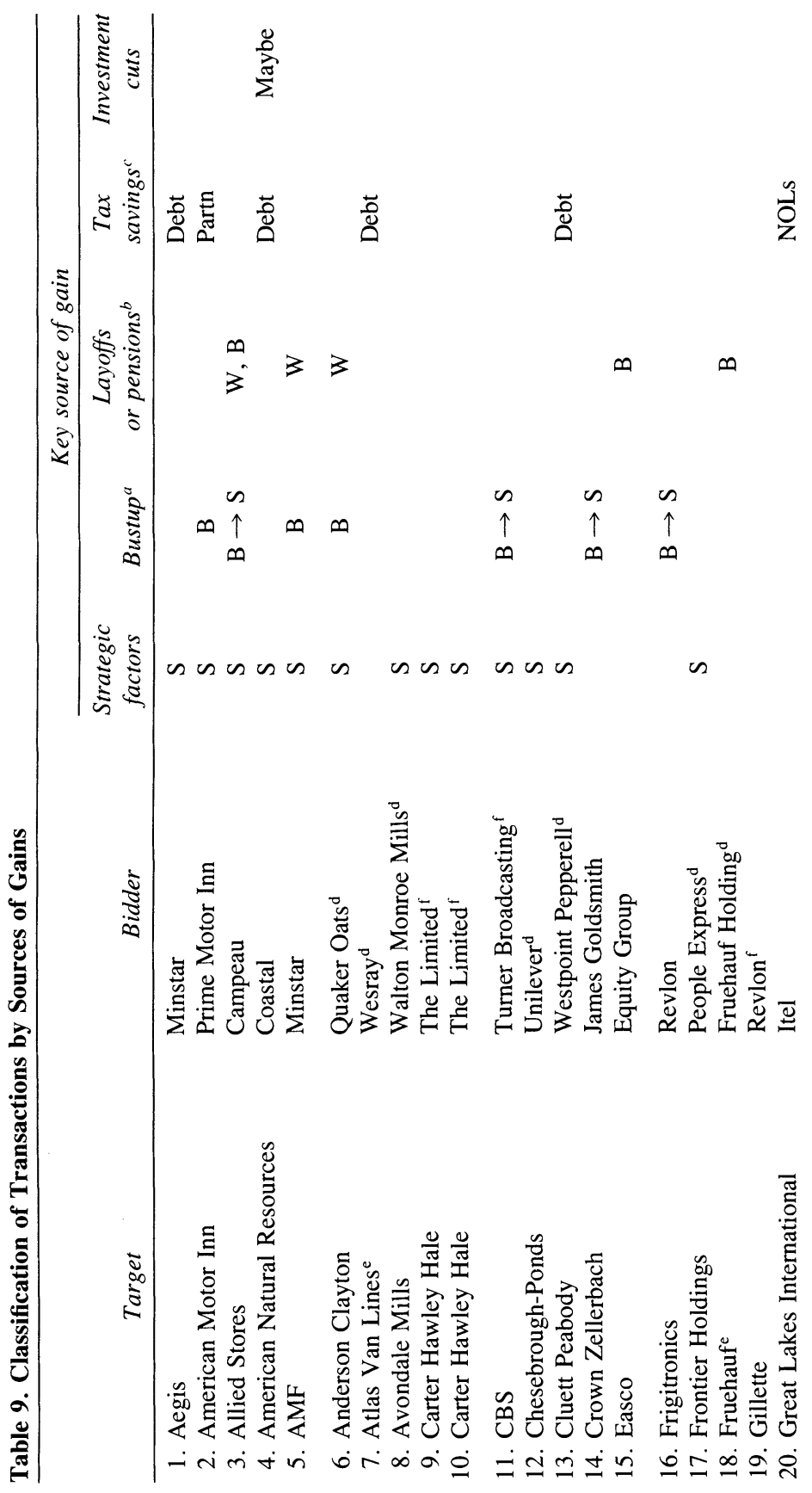




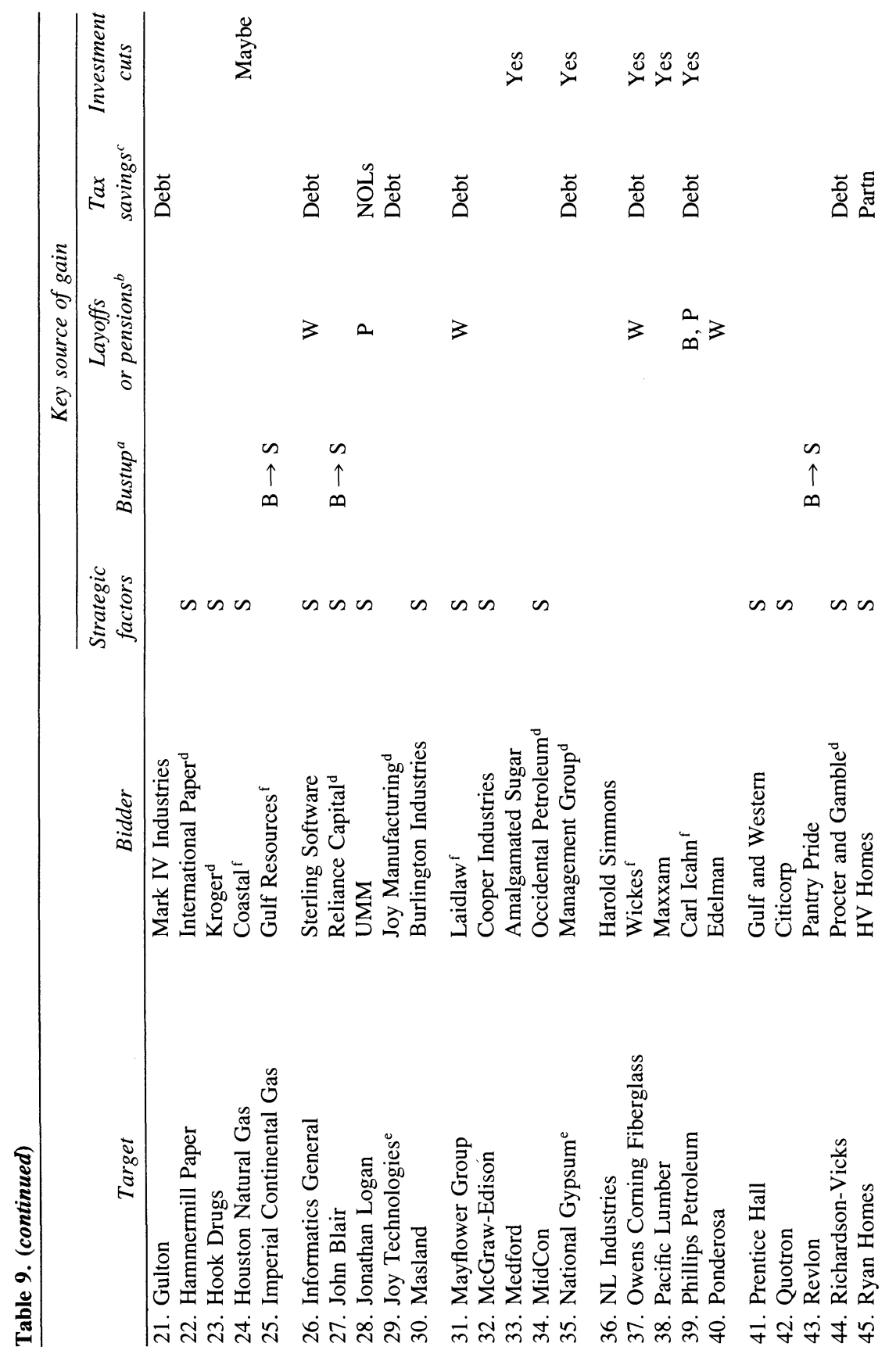




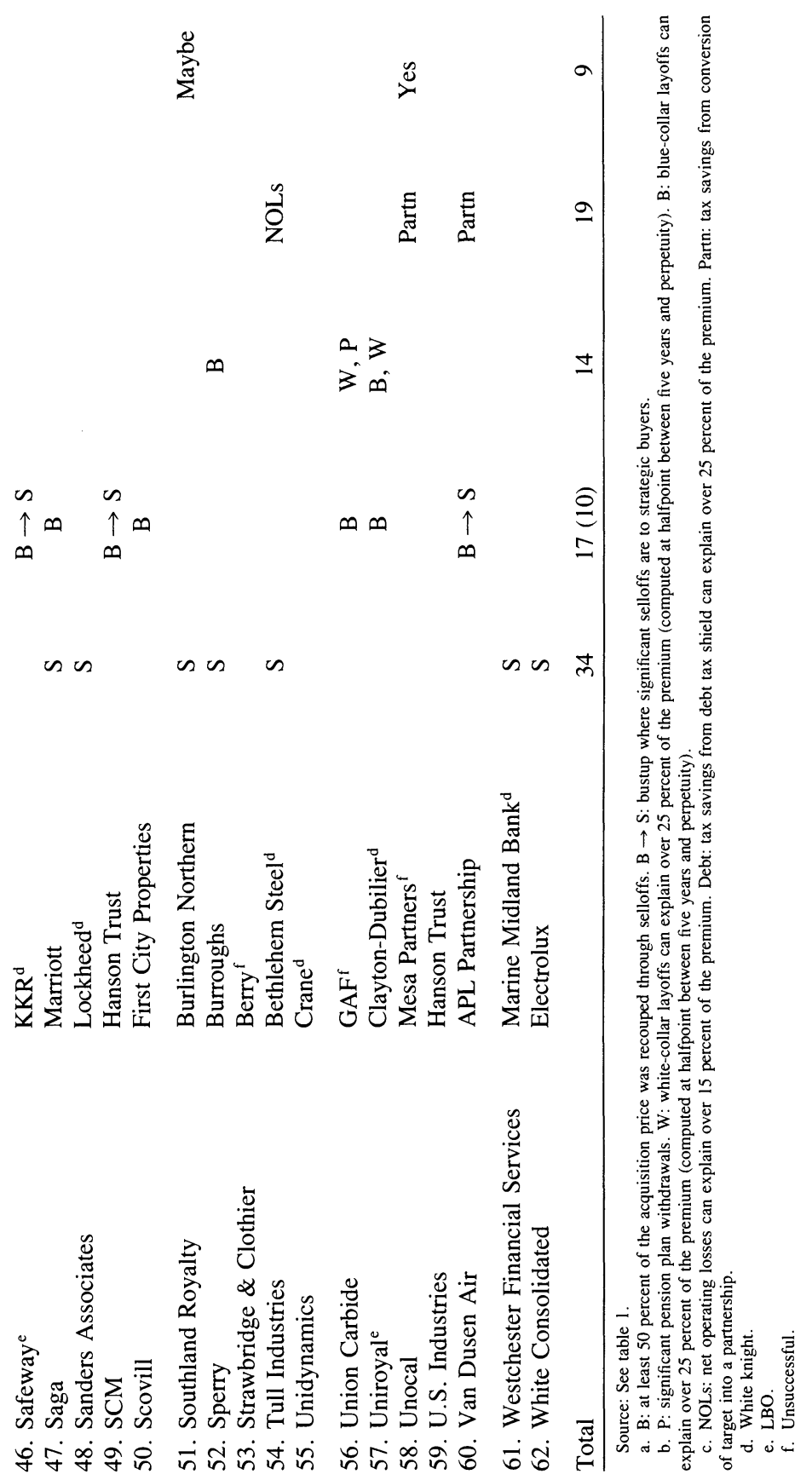


Table 10. Movement of Assets ${ }^{\mathrm{a}}$

\begin{tabular}{lcc}
\multicolumn{1}{c}{ Movement } & $\begin{array}{c}\text { Millions } \\
\text { of dollars }\end{array}$ & Percent \\
\hline Assets that changed hands & 68,743 & 100 \\
Assets that went to strategic buyers & 49,660 & 72 \\
Strategic acquisitions net of selloffs & 26,010 & 38 \\
Selloffs to strategic buyers & 23,650 & 34 \\
Assets that went to MBOs & 10,234 & 15 \\
Direct MBOs net of selloffs & 4,834 & 7 \\
Selloffs to MBOs & 5,400 & 8 \\
Assets that stayed with initial nonstrategic & & \\
bidders & 3,810 & 5.5 \\
Assets that went to unrelated acquisitions & 3,154 & 4.5 \\
Direct unrelated bidders & 373 & 0.5 \\
Selloffs to unrelated bidders & 2,781 & 4 \\
Selloffs of headquarters and other assets & 667 & 1 \\
Unidentified selloffs & 1,219 & 2 \\
\hline
\end{tabular}

Source: See table 1.

a. Total value of offers in the sample is $\$ 108.5$ billion. The value of assets that did not change hands was $\$ 39.7$ billion.

buying other firms in the same or a closely related industry. In the cases where the initial acquirer did not want the majority of the assets of the target company but only some divisions, we see a combination of a strategic acquisition and a bustup. (In these cases, there is an $\mathrm{S}$ in the first column and a B in the second column of the table.) Thus many apparent bustups turn out to be strategic in nature as well.

The first column of table 9 does not capture the full extent of strategic acquisitions. It does not consider the bustups that resulted in the sale of a significant fraction of the assets to other strategic buyers when the original acquirer was not strategically motivated. This adds another seven cases to the list of ultimately strategic transactions. Most of these are cases of takeover artists buying diversified firms and then selling off the pieces to strategic buyers.

When we add the number of strategic acquisitions to the number of nonstrategic acquisitions where the selloffs were largely to strategic buyers, we end up with 41 cases out of the total 62 , or 66 percent. These results are confirmed by value-weighted evidence in table 10 on who the eventual holders of the assets in our sample are. The total value of offers in our sample is $\$ 108$ billion. 
Of this value of assets, $\$ 39$ billion did not change hands. These assets were initially owned by targets that remained independent, and were not sold off by these targets. The remaining $\$ 69$ billion of assets changed hands, and the question is where they ended up.

As we see it, the assets could go to strategic buyers, to unrelated buyers, to MBOs or investment firms, to nonstrategic initial acquirers other than MBOs, to buyers of headquarters and other marketable assets in selloffs, and to unspecified buyers in selloffs. An asset can end up with a strategic buyer either if it is bought initially by a strategic buyer and then not sold off or if it is sold off by anyone to a strategic buyer. Similarly, there are two ways to end up owned by an MBO or held by an unrelated buyer: by being retained or by being acquired in a selloff.

As table 10 shows, of the $\$ 69$ billion of assets that changed hands, 72 percent ended up in the possession of strategic buyers. That 72 percent consisted of 38 percent that was retained by initial strategic buyers and 34 percent that was sold off to strategic buyers. By comparison, only 15 percent of assets ended up with MBOs or investment companies, 4.5 percent ended up with unrelated acquirers, 5.5 percent stayed with initial nonstrategic buyers, 2 percent went to unidentified buyers in selloffs, and 1 percent went to buyers of sold-off headquarters and other marketable assets.

The results again demonstrate the overwhelming importance of strategic acquisitions in this sample. If we assume, not implausibly, that the assets that ended up with MBOs or investment companies as well as the assets that were retained by nonstrategic buyers were managed by a new organizational form rather than by a corporation, we end up with 20.5 percent of all the assets that changed hands. That share is only 28 percent of the assets that went to strategic buyers. It is very clear that a movement to a new organizational form, where incentives are crucial, is not the steady state of most assets acquired in hostile takeovers. Rather, the steady state of an asset is being owned by a large public corporation in the same line of business as that asset. The primary motive behind hostile takeovers is not a change in incentives but an increase in the concentration of asset holdings.

The predominance of this allocation of resources suggests a relatively small role for incentive-intensive organizational forms, except perhaps for the purposes of implementing selloffs. It also suggests that unrelated acquisitions have become rare. There are only a few cases of unrelated 
diversification by buyers of divisions in this sample: Ralston Purina buying Eveready Batteries from Union Carbide, a British conglomerate buying Yale Lock from Scovill. There are also two cases of initial unrelated acquisitions, although in both cases the acquisitions are vaguely related. The time of unrelated diversification seems to be past. The idea is rather to bust up the conglomerates that have previously pursued unrelated diversification and to allocate divisions to strategic buyers. In fact, Bhide finds in his sample of post-takeover divestitures that only 3 out of 81 were companies divesting, directly through selloffs, a business they started; the rest were cases of divesting past acquisitions. ${ }^{32}$

This evidence raises the obvious question of where the gains in strategic acquisitions come from. In some cases, they may come from increases in market power. This, for example, seems quite possible in consolidation of pipelines following deregulation (American Natural Resources and Coastal, Midcon and Occidental Petroleum). Quaker Oats' acquisition of Anderson Clayton to keep Gaines dogfood was an explicit move to raise market share, although the link from market share to market power is not always evident. Minstar's acquisition of boat divisions of several companies also gave it a significant market share. Mergers of paper companies probably do not increase competition either. Many selloffs also raise concentration. KKR's selloff of some stores of Safeway was to buyers who already had significant market shares in the areas where the acquired stores operated. In these cases, declines in competition are potentially important.

Cost savings due to joint economies in management, production, distribution, and purchasing are also obviously important in strategic acquisitions. The classic example is the Burroughs takeover of Sperry that resulted in significant economies accompanied by massive layoffs. Some of the better deals negotiated with the suppliers and some of the gains from layoffs probably reflected wealth transfers rather than pure efficiency improvements. Significant cost savings were realized in Sterling Software's acquisition of Informatics as well. Some of the mergers we mentioned in discussing market power probably also led to cost cuts. These cuts might be another source of gains in strategic acqui- 
sitions, which may represent an efficiency gain rather than a transfer from consumers.

Last but not least, many strategic acquisitions result in declines in the value of acquiring firms, indicating the market's skepticism that the bid serves the interest of shareholders rather than the managers. We have presented some evidence on bidder value declines, although these numbers are subject to considerable error in estimation. The increase in combined values of bidders and targets in strategic acquisitions means either that large joint profit gains that we do not measure are realized or that the stock market in the 1980s, like the stock market in the 1960s, was excessively bullish on takeovers.

\section{Bustups}

In 17 of 62 cases, or about a quarter of the total, proceeds from selloffs amounted to at least 50 percent of the purchase price. In about half the 62 cases, the bustup was a side effect of a bidder's buying the whole company and keeping only the part that was wanted. Another significant fraction of bustups was engineered by raiders-for example, James Goldsmith-who specialize in selling the parts to strategic buyers. Bustups also occured after MBOs. After Clayton-Dubilier's selloffs at Uniroyal, the only retained division was tires, and even that division was eventually sold to a tire company. By and large, then, bustups fit very closely into the picture of strategic acquisitions. Either the original buyer in a hostile takeover keeps the parts it wants, often selling the others to strategic buyers as well; or the company is broken up and sold off largely to strategic buyers. In fact, 48 percent of assets that ended up with strategic buyers did so as a result of a selloff rather than of the original acquisition. The willingness of strategic buyers to pay a lot for these assets must be an important source of gains in bustups.

\section{Layoffs}

Table 9 marks 14 cases in which layoffs (or pension terminations) can explain at least 25 percent of the premium using the midpoint of the five-year and the perpetuity cost saving estimates. In 8 cases, the laid-off employees were only white-collar, in 3 cases they were only blue-collar, in 2 cases they were both, and in 2 cases pension plan terminations can account for a large chunk of the premium. Savings 
from white-collar employment cuts can account for a larger fraction of the premium.

White-collar employment cuts typically resulted from headquarters consolidations, although in a few cases (Union Carbide, Allied) there were massive white-collar layoffs. Even in the cases where headquarters reductions led to large cost savings, the takeovers were primarily strategic and would probably have occurred even if such savings were not possible. In only one case (Owens Corning Fiberglass), layoffs were of $R \& D$ staff, and it is sometimes argued that $R \& D$ expenditures in this company were excessively high. Treating layoffs as the primary motive for takeovers appears to be inappropriate, although they often are a significant source of gains.

\section{Taxes}

The source of gains that we have not so far treated systematically, but that we still believe to be important, is taxes. Table 9 notes 19 cases in which tax gains can probably account for at least 25 percent of the premium offered. Of these, 4 are cases in which the target became a partnership, 3 are cases of bidders with tax losses, and the rest are cases of large-debt tax shields. Of the 12 cases with significant debt tax shields, 6 are cases of successful takeovers by large corporations (all but 1 are clearly strategic) rather than leveraged recapitalizations by firms remaining independent or of LBOs.

In many cases in which a large debt was incurred in the acquisition, the firm proceeded to make large selloffs and pay back most of that debt. Since the value of the tax shield is limited by the duration of the debt, we try to get an estimate of how quickly the debt is paid down. We calculate the change in debt based on the firm's debt level two to three years after the acquisition for the purposes of the debt tax shields calculation. We take the present value of the tax benefits to be 0.2 times the additional debt. The 0.2 multiplier is consistent with either some Miller-type personal tax effects lessening the net tax advantage to debt or with gradual repayment of the debt over seven to ten years. We also had no handle on other tax benefits, such as accelerated depreciation under the general utilities doctrine. These issues require considerable further investigation. Our conjecture is that tax gains will prove to be somewhat important-probably about as important as layoffs. Tax gains might also help explain the puzzle of the increase in 
the combined value of the bidder and the target in some strategic acquisitions with few measured post-takeover changes.

\section{Investment Cuts}

Our analysis of investment cuts is severely limited by the scarcity of target-specific data. Table 9 marks nine cases in which investment cuts might be important. We note a few things about each of them.

In three cases the cuts were in the petroleum industry (Unocal, Phillips, and Southland Royalty) during the time of declining oil prices. These cases fit nicely Jensen's free cash flow theory, according to which oil companies continued to explore even when value maximization dictated a significant curtailment of exploration activities. Hostile takeover threats enforced this reduction in exploration (as well as adoption of limited partnership organizational form to save taxes). Although firms that were not targets of hostile takeovers also cut back exploration, they might have done it under the threat of takeover. The free cash flow story seems very plausible for oil.

Another industry in which severe investment cuts took place in the period of declining oil prices was gas pipelines, presumably because gas is a substitute for oil and its price falls when oil prices fall. If it is rational to curtail investment when the gas price declines, the observed cuts must be rational. In the case of gas pipelines, we do not believe the free cash flow story explains the takeovers. During this period the industry experienced deregulation and consolidation, with the effect that there were many mergers assembling pipeline systems to increase reliability of supplies as well as market power. There is virtually no public discussion of the objective of pipeline mergers being to stop investment rather than to create pipeline systems. Our view also fits with the mass of often successful antitrust suits following these mergers. The investment cuts after the takeovers thus do not seem to be driving these takeovers in the first place or even to be a by-product of these takeovers.

The third group of takeovers with investment cuts-or rather increases in disinvestment-is in timber. Most notable of these is Maxxam's takeover of Pacific Lumber, but there is also Amalgamated Sugar's takeover of Medford. In these two cases, the cutting of trees was sharply increased. The targets were apparently cutting too few trees given the interest rate, the growth rate of trees, and price path for timber. Pacific 
Lumber, in particular, had a huge forest of old redwoods that were not growing. The company was nonetheless not cutting them despite high interest rates, perhaps because it expected a secular rise in the price of old redwoods. Maxxam came in and cut the trees. Assuming away the possibility of disagreement over the future prices of these trees (market underpricing), we have a case in which cutting the trees raises efficiency. The Medford story is similar. This is not really a free cash flow case, since there was no cash that the target reinvested wastefully, but it is nonetheless a case in which disinvestment and partial liquidation were enforced by a takeover.

The final two cases are an LBO and a leveraged recapitalization where investment was cut and the debt raised very sharply (National Gypsum and Owens Corning). These may be free cash flow cases, but they may also be cases of cuts in useful investment because of limited access to capital. In both cases, much of the takeover premium can be explained with the debt tax shield, and in the case of Owens Corning there were large white-collar layoffs also. In a similar vein, Kaplan finds large investment reductions following MBOs more generally. ${ }^{33}$

In sum, the evidence on the free cash flow theory is mixed. It appears relevant in the case of oil. It might be relevant in the case of gas pipelines and in the case of LBOs, although the evidence is not compelling, especially with pipelines. In the case of timber, an amended version of the free cash flow theory might apply as well, although there is no free cash flow. Investment cuts are thus potentially important in 9 cases out of 62. In most other cases, particularly with strategic acquisitions, investment cuts are either ignored in all the discussions and reports we found, or else are not there. However, we do not think it is likely that lack of reporting is the whole story, since in the case of the oil industry, reports of investment cuts are very common. The conspicuous absence of such discussions for most other industries might indicate that investment cuts are simply unimportant.

\section{Summary and Conclusions}

Although we do not have the final answer on what drives hostile takeovers, several conclusions do emerge from the analysis.

33. Kaplan (1990). 
First, hostile takeovers largely allocate businesses to firms owning other related businesses. Firms acquire related firms both directly in the takeover and in selloffs after the takeover. Of the $\$ 69$ billion in assets that changed hands in our sample, 72 percent ended up in the hands of firms managing other similar assets. We do not know whether the gains in related acquisitions come from improvements in operating efficiency, increases in market power, or other sources.

Second, by comparison with strategic reallocation of assets, reallocation to MBO teams, investment groups, raiders, or other incentive-intensive organizations is only 20 percent of the total that changed hands. Raiders and MBO teams appear largely to serve the temporary function of brokering the transfer of assets toward related acquirers. High debt levels and concentrated ownership give these organizations a strong incentive to implement a bustup, but the task of subsequent management is left to others.

Third, layoffs are an important but not a dominant source of hostile takeover gains, accounting perhaps for 11 percent to 26 percent of the premium on average. Layoffs are disproportionately targeted at whitecollar employees, many of them in the course of consolidation of headquarters.

Fourth, selloffs are a pervasive consequence of hostile takeovers, and in many cases result in a liquidation or a near-liquidation of the target. A key objective of selloffs is to foster related acquisitions: over two thirds of the selloffs are to firms in a related business. Selloffs are smallest when the acquirer is a white knight.

Fifth, tax savings are important in some cases, particularly in LBOs, but the benefits of the debt tax shield are significantly reduced by the rapid repayment of debt. Tax losses and conversion to partnerships are less common but provide large benefits when they do take place.

Sixth, among the explanations of the sources of takeover gains that are important in some, but relatively few, cases are bidding shareholder losses and cuts of wasteful investment by the target firm. These are much less common sources of gains than layoffs or tax savings.

These findings suggest the following picture of the hostile takeover process of the 1980s. In the postwar period, aggressive antitrust enforcement prevented significant consolidation of U.S. industry and perhaps even encouraged the formation of conglomerates in the 1960s. Experience from the 1970 s showed that conglomerates are probably not 
the most profitable way to run businesses. ${ }^{34}$ The failure of conglomerates is revealed by the finding of Porter and of Kaplan and Weisbach that 40 percent to 60 percent of unrelated acquisitions were subsequently divested. ${ }^{35}$

In the 1980 s, the economy has again experienced a corporate liquidity boom. This increased liquidity has come in two forms. The first is greater internally generated cash flows in large corporations that want to make related (strategic) acquisitions. The second is a newfound ability to issue speculative-grade ("junk") bonds as a temporary financing tool while assets are being sold off. Junk bonds facilitated acquisitions by so-called "raiders" as well as by some strategic buyers. In addition, the most lenient antitrust enforcement in decades allowed the large pent-up demand for related acquisitions to be satisfied. Finally, heightened foreign competition and the deregulation of several key industries such as transportation, banking, and oil and gas increased the gains from intraindustry mergers. The takeover wave became the wave of related acquisitions. Much of this wave is reflected in the increased pace of friendly related acquisitions. But in addition, the pace of hostile takeovers skyrocketed. Many of the hostile takeovers, as well as acquisitions by white knights, aimed to deconglomerate large corporations and to allocate their various divisions to related acquirers. Raiders and $\mathrm{MBO}$ organizers in particular acquired diversified firms and sold off the parts to related acquirers, profiting handsomely from performing this brokerage function.

Although the expansion into related businesses drove the takeover process, several opportunities to raise the value of firms must have also encouraged hostile takeovers. The opportunities to cut overhead during consolidations by cutting headquarters staff as well as some common functions allowed nontrivial cost savings that certainly helped the process, although they did not drive it. Tax subsidies to debt clearly helped the raiders and $\mathrm{MBO}$ organizers to realize some gains, although the opportunity to unload the assets on strategic buyers must have been crucial. The fact that the typically strategically motivated white knights reap fewer gains from layoffs and selloffs than hostile acquirers suggests

34. Ravenscraft and Scherer (1987).

35. Porter (1987) and Kaplan and Weisbach (1990). 
that these changes are not the most essential source of gains from consolidation.

Our evidence also shows what hostile takeovers are not. They are not typically a reflection of change in the internal organization of the firm. Management buyouts and acquisitions by raiders are often a temporary step in the reallocation of assets; they are not a new permanent organizational form. The eventual holders of assets are large public corporations, which are not about to be eclipsed.

This interpretation of hostile takeovers in the 1980s offers several tentative conclusions for policy analysis. First, hostile takeovers do not result in massive employment cuts in acquired companies. State antitakeover laws that aim to stop takeovers to protect blue-collar workers are misguided. Since such laws probably stop some takeovers that foster specialization of corporations, they are more likely than not to reduce efficiency. Second, Reagan's lenient antitrust enforcement of the 1980s indirectly fostered deconglomeration of the U.S. economy. Since the experience with conglomerates seems almost uniformly disappointing, the move toward specialization probably on balance raises efficiency. In some cases, competition is probably reduced, but our case studies suggest that there are many business reasons for related acquisitions other than to raise prices. Unfortunately, we do not have the highly disaggregated market share data necessary to evaluate the precise scope for increased market power in our sample of acquisitions. On balance, however, the evidence suggests to us that the Reagan antitrust stance has had a positive influence on the economy.

Our analysis leaves open the key question: where do the value gains in strategic acquisitions come from? The fact that in a typical strategic acquisition the combined wealth change of the bidding and target shareholders is positive suggests that the market believes these gains do exist. We have identified some sources of efficiency improvements and other gains, such as headquarters layoffs and tax savings, but they clearly are not the whole story. There may be many efficiency gains in production, procurement, and distribution that we have no way of capturing. Gains from market power might also be relevant, but the evidence on the existence of these gains is inconclusive. Finally, the value gains recorded may simply reflect the market's overestimation of the value of strategic combinations, just as the market overestimated the gains to conglomerate mergers in the 1960s. This may be reflected 
either in too low a share price for the pre-takeover target firm or in too high a price for the post-takeover acquirer or those buying divested divisions of the target at high prices. In part, the market may currently be underpricing conglomerates relative to undiversified companies. All of the above sources of gains are potentially important. We appear to have reduced the scope of the problem to that of related acquisitions, but that problem remains wide open.

\section{Appendix: Brief Summaries of Deals}

In this appendix, we present a brief summary of what we believe to be important sources of target shareholder wealth gains in each one of our 62 hostile takeover attempts. We bring in the earlier evidence on bidding shareholder wealth changes, layoffs, and selloffs when such evidence is pertinent, but also discuss taxes, investment changes, and possible stock market underpricing when we believe these are important. In addition, we document the cases where strategic motives appear to play a role, that is, how often the bidder and the target are in the same or in closely related businesses. Equity refers to the purchase price of equity, debt to the pre-takeover value of debt, and premium to the premium computed in the text.

1. Minstar buys Aegis. Equity $\$ 59$ million; debt $\$ 20$ million; premium $\$ 22$ million. Selloff of Cherco Compressors and Turboscope, the latter bought as part of AMF, for $\$ 150$ million, but don't know how much is from Aegis. Some operations discontinued, but no clear layoffs. $\$ 3$ million taken from the pension fund. $\$ 53$ million in additional debt is taken on by Minstar so taxes may play a role. Primarily, this seems to be a strategic acquisition. Minstar makes boats and is interested in the boat division of Aegis.

2. Prime Motor Inn buys American Motor Inn. Equity $\$ 238$ million; debt $\$ 67$ million; premium $\$ 60$ million. Selloffs of $\$ 383.7$ million, with 12 Holiday Inns retained. Over half of selloffs are to limited partnerships with Prime leasing some of them back. There was an increase in investment (refurbishing). No layoffs. This is partly a strategic acquisition with Prime now managing many of the former AMI properties. It is 
also a bustup, motivated largely by the tax benefits of the limited partnership form of organization (only one layer of tax).

3. Campeau buys Allied Stores. Equity $\$ 3.7$ billion; debt $\$ 664$ million; premium $\$ 1.11$ billion. Selloffs of at least $\$ 2.5$ billion. Remaining divisions generate about 50 percent of revenue. Assumes about $\$ 3$ billion in additional debt but with very rapid payback through selloffs. Layoffs of at least 2,625: 600 headquarters, 2,025 blue-collar; savings of between $\$ 270$ million and $\$ 705$ million in present-value terms. This appears to be a strategic bid for Allied's shopping centers (Campeau is a shopping center developer), but the premium may derive from profitable asset selloffs and savings from layoffs.

4. Coastal buys American Natural Resources. Equity $\$ 2.46$ billion; debt $\$ 1,065$ billion; premium $\$ 763$ million. No selloffs. Assumes $\$ 1.9$ billion in additional debt with fairly slow pay down. Some job reduction and a sharp decrease in investment, but this is true throughout the industry. Appears to be a strategic bid stemming from the post-deregulation consolidation in the pipeline industry. The market seems to like Coastal's strategy; its market value rose by $\$ 117$ million around the announcement of its bid.

5. Minstar buys $A M F$. Equity $\$ 545$ million; debt $\$ 170$ million; premium $\$ 74$ million. Selloffs of at least $\$ 511$ million (although Minstar CEO Jacobs says $\$ 535$ million). Retained several AMF businesses accounting for approximately 20-25 percent of pre-acquisition operating profit and $\$ 350$ million in book value. In particular, kept boat division, Hatteras, which fits into Jacobs' strategy of acquiring boat manufacturers. Cut 350 staff positions with present value of saving between $\$ 67$ million and $\$ 175$ million. Strategic bid for part of company combined with a profitable bustup and large savings from headquarters layoffs.

6. Quaker Oats buys Anderson Clayton as a white knight. Equity $\$ 805$ million; debt $\$ 19$ million; premium $\$ 108$ million. Sells off all but Gaines dogfood for $\$ 535$ million. Anderson Clayton had $\$ 240$ million in cash. This means $\$ 50$ million for Gaines. Previously offered $\$ 250$ million for Gaines alone. Headquarters staff reduction with presentvalue of savings of at least $\$ 145$ million. Strategic bid for part of company, combined with a very profitable bustup and headquarters layoffs. Market value of Quaker Oats declines by $\$ 165$ million when 
acquisition is announced, suggesting that market did not anticipate such a profitable bustup.

7. Wesray buys Atlas Van Lines in a white knight LBO. Equity $\$ 72$ million; debt $\$ 4.6$ million; premium $\$ 27$ million. Assumed $\$ 70$ million additional debt. No selloffs. Evidence that employment declines from over 600 to 524 over two years, but no mention of layoffs. Debt tax shield can explain most of the premium.

8. Walton Monroe Mills buys Avondale Mills as a white knight. Equity $\$ 113$ million; debt $\$ 37.6$ million; premium $\$ 38$ million. Intended selloffs of about $\$ 18$ million. No layoffs, but information is scarce because the acquirer is private. $\$ 4.5$ million from pension fund. Largely a strategic acquisition; Avondale is the exclusive marketer of Walton Monroe products and also buys a large quantity for its own account.

9. The Limited unsuccessfully tries to buy Carter Hawley Hale (1984). Equity $\$ 1.1$ billion; debt $\$ 521$ million; premium $\$ 397$. Selloffs of $\$ 333$ million. No evidence of layoffs. Appears to be a strategically motivated acquisition attempt possibly with bustup elements.

10. Retail Partners (including the Limited) unsuccessfully tries to buy Carter Hawley Hale (1986). Equity $\$ 1.95$ billion; debt $\$ 700$ million; premium $\$ 1.16$ billion. Selloffs of $\$ 213$ million. However, also spin off most valuable properties to shareholders, including NeimanMarcus, Bergdorf-Goodman, Contempo Casuals. No evidence of layoffs. Again, seems to be strategic, with elements of a bustup.

11. Turner Broadcasting tries unsuccessfully to buy CBS. Equity $\$ 5.41$ billion; debt $\$ 371$ million; premium $\$ 2.75$ billion. Defensive response by CBS is a leveraged recapitalization with selloffs of at least $\$ 3.44$ billion, but the most valuable assets remain. Partly these selloffs are profitable because of a rise in the market as a whole over the two years following the Turner bid. Present value of savings from layoffs between $\$ 238$ million and $\$ 627$ million. Capital expenditures in the broadcast division are cut by $\$ 30$ million. This appears to have been a strategic bid by Turner for part of the company (broadcasting), but the bid may have also been motivated by gains from bustup and layoffs. Seems to have elements of everything.

12. Unilever buys Chesebrough-Ponds as a white knight. Equity $\$ 3.1$ billion; debt $\$ 1.17$ billion; premium $\$ 1.44$ billion. Selloffs are more than $\$ 1.8$ billion, largely consisting of Stauffer Chemical that $\mathrm{CP}$ 
bought shortly prior to being itself acquired. Layoffs save between $\$ 30$ million and $\$ 80$ million in present value terms. Strategic bid for the core business, which is personal hygiene and health care products. This fits with Unilever's strategic objective to gain a larger U.S. presence in these products for purposes of exploiting its superior $R \& D$.

13. Westpoint Pepperell buys Cluett Peabody as a white knight. Equity $\$ 375$ million; debt $\$ 124$ million; premium $\$ 77$ million. No layoffs. No selloffs. West Point assumes approximately $\$ 125$ million in additional debt, which it does not pay down quickly. Appears to be a strategic acquisition motivated by Westpoint's desire to acquire more brand names including several international brands of Cluett.

14. James Goldsmith buys Crown Zellerbach (no white knight found). Equity around $\$ 1.2$ billion; debt $\$ 648$ million; premium $\$ 193$ million. Selloffs of at least $\$ 1.15$ billion, mostly to strategic buyers. Goldsmith is after Crown Zellerbach timberland, which he considers undervalued. This is clearly a bustup, possibly with elements of underpricing by the stock market of timber assets or too slow harvesting by Crown as in the Pacific Lumber case (see below).

15. Equity Group buys Easco. Equity $\$ 175$ million; debt $\$ 90$ million; premium $\$ 27$ million. Selloffs of $\$ 13$ million. Acquirer is interested in the hand tool business of Easco as evidenced by its buying 100 percent of this business from remaining shareholders of Easco. Hand tool business is in the midst of dramatic turnaround clearly started before the bid (but not finished until after). There is a reduction of employment from 3,065 to 2,184 with a large rise in sales per employee. At least 350 of these 881 layoffs take place before the bid, and the manager brought in to lead the turnaround is kept on by the acquirer. Layoffs of this magnitude can easily explain the premium paid. The only question is whether the acquisition was needed to speed up the turnaround or whether the acquirer was simply more willing than the market to bet on the results. Easco Hand Tools goes public again in 1987.

16. Revlon buys Frigitronics after a failed LBO. Equity $\$ 115$ million; debt $\$ 8$ million; premium $\$ 41$ million. Asset selloffs of at least $\$ 120$ million, largely to strategic buyers. No layoffs. Complete bustup and liquidation-both planned from the start.

17. People Express buys Frontier Holdings as a white knight. Equity $\$ 307$ million; debt $\$ 35$ million; premium $\$ 117$ million. No layoffs by 
agreement with People's. No asset selloffs until bankruptcy. People tries to turn Frontier into a no-frills airline but the strategy does not work out as Frontier is badly hurt by fare wars in its major markets. After that, People tries to sell Frontier to United for $\$ 146$ million, but fails. Instead, United buys hangars, gates, etc., for $\$ 50$ million. Eventually bought by Texas Air for $\$ 174$ million, including assumption of debt. Initial acquisition is clearly strategic. Part of People's ill-fated expansion program.

18. Fruehauf $L B O$ as defense against Edelman. Equity $\$ 1.1$ billion; debt $\$ 480$ million; premium $\$ 414$ million. Selloffs of at least $\$ 732$ million, but kept automotive business and domestic truck trailers divisions representing over 80 percent of pre-acquisition operating profit. Close to bankruptcy soon after the buyout. Assumed $\$ 500$ million in additional long-term debt and $\$ 400$ million- $\$ 500$ million in additional short-term debt at time of buyout. After 1.5 years had $\$ 400$ million of the additional long-term debt remaining. Layoffs of 730 to save between $\$ 55$ million and $\$ 146$ million in present-value terms. Basically, management forced into bustup/restructuring LBO, but probably overpayment by the LBO group combined with industry shocks to the trailer and container businesses.

19. Revlon unsuccessfully tries to buy Gillette. Equity $\$ 4.12$ billion; debt $\$ 436$ million; premium $\$ 1.48$ billion. Selloffs of $\$ 50$ million. Planned layoffs will save between $\$ 182$ million and $\$ 480$ million in present-value terms. The bidder probably intended a much more radical bustup and restructuring than actually occurred as evidenced by low level of Gillette's share price after fending off Revlon.

20. Itel Corporation buys Great Lakes International. Equity $\$ 170$ million; debt $\$ 30$ million; premium $\$ 14$ million. Selloffs of $\$ 31$ million. Itel has large tax loss carryforwards, and Great Lakes is showing profit. Also, Itel may be betting on legislation passed shortly after acquisition, which is a huge boon to Great Lakes' offshore dredging business. Small premium can easily be explained by taxes.

21. Mark IV Industries buys Gulton. Equity $\$ 113$ million; debt $\$ 9$ million; premium $\$ 36$ million. Insubstantial selloffs. Appears to take on approximately $\$ 100$ million in additional long-term debt, which is not paid down quickly, although it is difficult to attribute all that debt to Gulton acquisition. Some headquarters layoffs, but cannot document 
numbers. Mark IV assembles a diversified portfolio of small high-tech businesses in various industries and simply reallocates capital among them. Mark IV market value declines by $\$ 6$ million on announcement of bid.

22. International Paper buys Hammermill Paper as a white knight. Equity $\$ 1.1$ billion; debt $\$ 310$ million; premium $\$ 418$ million. Small selloffs. No layoffs. Strategic.

23. Kroger buys Hook Drugs as a white knight. Equity \$161 million; debt $\$ 13$ million; premium $\$ 74$ million. No selloffs initially. Hook is supposed to be well run. Subsequently Kroger sells off Hook and its own drug chain, Superex, to management team for $\$ 490$ million. Not clear how much is Hook, but conjectured $\$ 100$ million-\$200 million. Kroger is said to lose a little on Hook overall. Initial intention is clearly strategic; alleged synergies in pharmaceutical purchasing and private label procurement. Does not appear to have worked out. Kroger's market value falls by $\$ 26$ million on announcement of its bid.

24. Coastal tries unsuccessfully to buy Houston Natural Gas. Equity $\$ 2.72$ billion; debt $\$ 360$ million; premium $\$ 961$ million. Defensive response by HNG is leveraged recapitalization/share buyback plan. Initially, $\$ 700$ million in additional debt is assumed. Selloffs of more than $\$ 544$ million. No evidence of layoffs at this stage. HNG acquires two additional pipelines in 1984. Strategic bid à la Coastal/ANR; postderegulation consolidation in pipeline industry. Within two years, HNG is acquired by Internorth in a friendly acquisition.

25. Gulf Resources unsuccessfully tries to buy Imperial Continental Gas (a British Company). Equity 753 million pounds; some debt; premium 155 million pounds. Defensive response of IC Gas is to be split into two companies, the first containing the firm's sought after Belgian assets. After spinoff the Belgian assets were acquired for 448 million pounds. The second piece of IC Gas later rejects a bid for 821 million pounds, but then spins off a subsidiary valued at 300 million pounds. A clear attempted bustup.

26. Sterling Software buys Informatics General. Equity $\$ 126$ million; debt $\$ 1$ million; premium 28 million. Selloffs of at least $\$ 34$ million. Sterling assumes $\$ 100$ million in additional debt. Initial goal is to reduce debt to $\$ 50$ million, but two years later only reduced by \$20-30 million. Eliminate entire corporate staff (60 domestic and 50 
international employees). Present value of the after-tax savings is $\$ 22-$ 60 million. Layoffs suffice to explain most of the premium, although debt tax shields may explain a large part of the premium. Also, this is clearly a strategic acquisition.

27. Reliance Capital buys John Blair as a white knight. Equity $\$ 356$ million; debt $\$ 240$ million; premium $\$ 165$ million. Selloffs at least $\$ 377$ million. Keep Spanish TV stations that Reliance also has. No evidence of layoffs. Strategic bid for part of company.

28. UMM buys Jonathan Logan (over unsuccessful defensive LBO). Equity about $\$ 196$ million; debt $\$ 18$ million; premium $\$ 16$ million. Selloffs of $\$ 17$ million. Substantial layoffs but most appear to be at UMM rather than Jonathan Logan. UMM did phase out ladies' apparel division of JL. Pension transfer of $\$ 15$ million. UMM has some tax losses. Pension transfer along with better use of tax losses can explain the small premium here, although the original motives seem to have been strategic.

29. Joy Technologies makes a defensive LBO of Joy Manufacturing. Equity $\$ 620$ million; debt $\$ 96$ million; premium $\$ 229$ million. Selloffs are at least $\$ 252$ million plus assumption of some liabilities. Retained divisions represent at least 75 percent of pre-acquisition operating income. No evidence of layoffs. Approximately $\$ 400$ million in additional debt taken on, so tax benefits may be important. Motivation for LBO is to remain independent; premium can probably be explained by profitable partial bustup coupled with tax benefits.

30. Burlington Industries buys Masland. Equity $\$ 117$ million; debt $\$ 19.5$ million; premium $\$ 42$ million. No selloffs. No layoffs. Strategic acquisition. After Burlington LBO in 1988, Masland division put on the block. It is sold for $\$ 79$ million plus $\$ 66$ million in preferred stock. Burlington lost $\$ 80$ million around the announcement of its bid.

31. Laidlaw tries unsuccessfully to buy Mayflower. Equity $\$ 260$ million, debt $\$ 60$ million; premium $\$ 63$ million. Defensive response of Mayflower is a leveraged recapitalization. Approximately $\$ 150$ million in additional long-term debt after two years. Selloffs of $\$ 25$ million. Layoffs of 125 people bring savings of $\$ 24$ million-63 million in present-value terms. Also, may be exploiting unused debt capacity in a low-risk mature firm (school bus operator). Layoffs and debt tax shields can probably explain the premium. Strategic element is also important 
as Laidlaw and Mayflower are the two biggest firms in the school bus business.

32. Cooper Industries buys McGraw-Edison. Equity $\$ 1.1$ billion; debt $\$ 300$ million; premium $\$ 410$ million. Selloffs of $\$ 177$ million that can be identified; Moody says $\$ 260$ million. In either case, keep vast majority of assets. Some layoffs at a McGraw-Edison unit headquarters and some plant shutdowns. Strategic acquisition with some evidence of restructuring.

33. Amalgamated Sugar (Harold Simmons) buys Medford. Equity $\$ 108$ million; debt $\$ 37$ million; premium $\$ 49$ million. Selloffs of $\$ 38$ million. Large stepup in harvesting trees. Probably a similar story to Pacific Lumber. Either underpriced or underutilized timber resources. Is there a general violation of Hotelling pricing of timber or just a lot of heterogeneity in types of timber, tree growth rates, and so forth?

34. Occidental Petroleum buys MidCon as a white knight. Equity $\$ 3.1$ billion; debt $\$ 800$ million; premium $\$ 1.4$ billion. Selloffs of at least $\$ 1.47$ billion. Layoffs of 2,000, saving between $\$ 152$ million and $\$ 400$ million in present-value terms. Approximately $\$ 80$ million cut in capital expenditure. Not clear these layoffs and capital spending cuts are abnormal given what is happening in the industry right around the time of the acquisition. Appears to be a strategically motivated acquisition with Oxy trying to acquire pipelines to transport its gas. Later Oxy loses civil lawsuit saying that tried to monopolize regional gas distribution through MidCon acquisition. Oxy's market value declines by $\$ 365$ million on announcement of Midcon bid; fits with Oxy's typical pattern.

35. National Gypsum LBO (defensive against Wickes). Equity $\$ 1.6$ billion; debt $\$ 120$ million; premium $\$ 325$ million. Assume approximately $\$ 1.3$ billion in additional long-term debt. Fairly slow debt reduction over time. Selloffs of at least $\$ 441$ million. No layoffs we can identify. Cut investment from $\$ 91$ million to $\$ 24$ million. Not clear that this is wasteful investment. Tax savings from higher debt can justify much of the premium. Free cash flow story may be important.

36. Harold Simmons buys NL Industries after unsuccessful bid by Coniston. Offers $\$ 900$ million for the firm (plus debt of $\$ 231$ million), but ends up buying control of the firm on the open market. Firm consists of very profitable chemicals business and not very profitable oil rigs 
business. As a defensive response NL has spun off NL Chemicals with most of its cash flow going to a new class of preferred stock. Initially Simmons purchases 51 percent of the parent firm (supposedly obtaining control and cash flow claims to oil business) and 20 percent of the preferred stock with cash flow claims to chemical business. Premium in this initial purchase is negligible or negative. Ultimately, Simmons is after the chemical business and over time accumulates a majority of the preferred stock. His attempts to sell off chemicals to his own firm fail despite having 51 percent of the votes in the parent. In the meantime, the chemicals business (primarily titanium dioxide) is taking off due to shortages, and a subsequent LBO offer of $\$ 915$ million for chemical subsidiary alone is rejected as too low. No selloffs. Pension plan terminated: \$81 million received after tax. Employment falls very sharply in the petroleum business, but this is typical of the whole industry. Pension transfer can explain the premium, but most likely the company was significantly underpriced because the potential of chemical business was not appreciated by the market. At least this seems to be what is motivating Simmons.

37. Wickes tries unsuccessfully to buy Owens Corning Fiberglass. Equity $\$ 2.1$ billion; debt $\$ 540$ million; premium $\$ 528$ million. Defensive response of Owens is leveraged recapitalization/share buyback. Take on $\$ 2$ billion in additional debt, but pay down about $\$ 1$ billion of that within one to two years. After three years still have approximately $\$ 800$ million in additional debt. Selloffs at least $\$ 501$ million; $\$ 679$ million according to Moody's. Layoffs of 480 R\&D personnel; also early retirement of 373 at headquarters. Estimated present value of saving from research personnel layoffs alone is between $\$ 91$ million and $\$ 240$ million. There is some evidence that Owens has been spending a lot on research without significant results. Early retirements save perhaps another $\$ 70$ million- $\$ 186$ million. Also significant capital spending cuts. Can trace approximately $\$ 30$ million a year of those cuts to nondivested businesses. Motivation of Wickes is a little unclear. Owens defensive restructuring works to boost share price even a little above the level of the bid. Research and headquarters employment reductions, some tax savings from increased debt, and elimination of possibly wasteful capital expenditures can probably explain this.

38. Maxxam buys Pacific Lumber. Equity $\$ 870$ million; debt $\$ 46$ million; premium $\$ 256$ million. Selloffs of $\$ 351$ million. Withdrawal 
of $\$ 50$ million from pension plan. Sharply step up cutting old redwood trees, which the previous management left untouched. Employment rises to accommodate higher output. Subsequent appraisal of timber assets at $\$ 2.1$ billion. A little unclear how much this is case of timber assets being underpriced by the stock market and how much the old management was wasting by harvesting too slowly. There is some evidence for the view that the old management's slow harvesting policy was suboptimal.

39. Pickens tries unsuccessfully to buy Phillips Petroleum (Icahn also involved). Equity $\$ 8.5$ billion; debt $\$ 2.84$ billion; premium $\$ 1.22$ billion. Defensive response of Phillips is leveraged recapitalization/ share buyback plan. Assumed approximately $\$ 3.7$ billion of additional debt. Three years later still had $\$ 2$ billion in additional debt. Selloffs at least $\$ 2$ billion. Sharp exploration cutbacks. Large layoffs (saving between $\$ 467$ million and $\$ 1.23$ billion in present-value terms). Pension excess of $\$ 400$ million. Possibly utilization of unused debt capacity (tax shields). Premium can be explained by layoffs and cutbacks in wasteful exploration, although there is a big question about how much would have been cut even without takeover threat. Post-recapitalization projections for exploration spending do not contain severe cuts but talk about the possibility of such cuts if oil prices fall substantially (which happened in the year after the recap). Taxes may also be important here: not only exploitation of unused debt capacity, but also Pickens may have been interested in spinning off oil and gas properties into a partnership or trust to avoid double taxation.

40. Edelman buys Ponderosa after another takeover bid is defeated. Equity $\$ 280$ million; debt $\$ 48$ million; premium $\$ 68$ million. Assumed about $\$ 270$ million in additional debt. Selloffs of $\$ 17$ million not including sale of office building, corporate jet, and art collection; other planned selloffs failed. Headquarters layoffs save between $\$ 22.8$ million and $\$ 60$ million in present value. Cut capital spending from $\$ 63$ million to $\$ 20$ million. Sold whole company to Metromedia in 1988 at a small loss rather than put in a mere $\$ 8$ million- $\$ 10$ million more in equity capital. Apparently intended more piecemeal selloffs, although layoffs and debt tax shields should easily explain the premium with unclear value enhancement role for capital spending cuts.

41. Gulf and Western buys Prentice Hall. Equity $\$ 705$ million; debt $\$ 3$ million; premium $\$ 254$ million, but G\&W declines by $\$ 59$ million. 
No layoffs, no selloffs. Strategic bid: both companies are publishers.

42. Citicorp buys Quotron. Equity $\$ 680$ million; debt $\$ 7$ million; premium $\$ 137$ million. No selloffs. No layoffs. Strategic acquisition fits Citicorp's plan to move into information services.

43. Pantry Pride buys Revlon. Equity $\$ 1.8$ billion; debt $\$ 485$ million; premium $\$ 256$ million. Selloffs of assets are at $\$ 2.06$ billion largely to strategic buyers in the health care business, but the main cosmetics business is kept. Rejects offer to sell cosmetics for $\$ 905$ million. Revlon also has $\$ 420$ million in cash. Classic bustup although may have also improved cosmetics operations. Allegedly the cosmetic business received the attention and resources (advertising budget) it needed after health care business was sold off.

44. Procter and Gamble buys Richardson-Vicks as a white knight. Equity $\$ 1.66$ billion; debt $\$ 170$ million; premium $\$ 776$ million, but P\&G loses $\$ 165$ million on the announcement. Approximately $\$ 1$ billion in additional long-term debt is assumed by $P \& G$ and this is not reduced in the two years after the acquisition. Selloffs at least $\$ 106$ million. No layoffs even though there was some talk about efficiencies from combining sales forces. Take on $\$ 1.5$ billion in debt. Clearly a strategic acquisition. P\&G wants international distribution channels of Richardson-Vicks to increase sales of its products overseas and wants to use its own bargaining power in purchasing advertising to benefit $R-V$ products in U.S.

45. HV Homes (a limited partnership) buys Ryan Homes. Equity $\$ 330$ million; debt $\$ 18$ million; premium $\$ 64$ million. No selloffs. No layoffs. Conversion to limited partnership has large tax benefits, as does the increase in debt. Also, acquirer argued that strategic considerations are important. Tax savings can explain the premium, however.

46. KKR buys Safeway as a white knight defense against Dart Group bid. Equity $\$ 4.2$ billion; debt $\$ 1.1$ billion; premium $\$ 1.5$ billion. Layoff of $300 \mathrm{HQ}$ staff for a saving of between $\$ 57$ and $\$ 150$ million in PV terms. Selloffs of at least $\$ 3.2$ billion. Stores representing at least 70 percent of sales are kept. Sold-off stores seem to be the higher labor cost stores (depending on local union and labor market conditions). Some concerns that union workers will be squeezed. Also, each regional piece of the firm seems to be sold to other players with lots of stores in that region (for example, Vons Grocery in Southern California), 
perhaps with the intention of raising market power. Taxes and layoffs alone cannot explain the premium; bustup must be important.

47. Marriott buys Saga. Equity $\$ 502$ million; debt $\$ 105$ million; premium $\$ 148$ million, but Marriott loses $\$ 162$ million in value. Selloffs of $\$ 306$ million. Combined operations and support staff but no layoff numbers are available. Keeps foodservice business. Strategic bid for part of the company.

48. Lockheed buys Sanders Associates as a white knight. Equity $\$ 1.18$ billion; debt $\$ 19$ million; premium $\$ 614$ million. Some layoffs, but small relative to the premium. No selloffs. Strategic bid, both do defense.

49. Hanson Trust buys SCM. Equity $\$ 927.5$ million; debt $\$ 261$ million; premium $\$ 386$ million. Selloffs of at least $\$ 900.2$ million mostly to strategic buyers, but kept typewriter division and titanium dioxide assets representing almost 50 percent of pre-acquisition operating income. No evidence of layoffs. Seems like a clear bustup.

50. First City Properties buys Scovill. Equity $\$ 540$ million; debt $\$ 87$ million; premium $\$ 212$ million. Selloffs of at least $\$ 680.7$ million, but a division with book value of assets of over $\$ 100$ million and at least 25 percent of pre-acquisition operating profit is retained. Cuts in corporate staff of 30-35 percent as well, exact numbers are not known. The crown jewels of Scovill (Nutone and Yale Security) were sold off about 2.5 years after the acquisition near the market's peak (and accounted for $\$ 480$ million of the proceeds from selloffs).

51. Burlington Northern buys Southland Royalty (after the latter tries to reorganize as a limited partnership to reduce tax bill). Equity $\$ 695$ million; debt $\$ 339$ million; premium $\$ 126$ million, but $\mathrm{BN}$ loses $\$ 97$ million in value. No selloffs. Big reductions in BN pipeline work force (30 percent), unclear how many from Southland Royalty. Some investment reductions. Layoffs and investment cuts are quite typical of the entire industry around this time. Motive appears to be strategic; Southland is a big supplier to BN's pipelines. Burlington falls by almost full amount of premium paid for Southland. Eventually, Burlington Northern spins off Southland Royalty and other natural resources into Burlington Resources, a limited partnership when it itself becomes a target. 
52. Burroughs buys Sperry. Equity $\$ 4.44$ billion; debt $\$ 1.03$ billion; premium $\$ 1.22$ billion. Selloffs of at least $\$ 1.8$ billion. Layoffs of at least 2,370 for a saving of $\$ 180$ million to $\$ 474$ million. Actual employment reductions are much bigger than layoffs, at least 10,000 through early retirement, attrition, and layoff. That means total savings of $\$ 760$ million to $\$ 2$ billion. Employment cutbacks are a big source of gain. Also, other efficiencies, including a purchase of inputs. Allegedly save $\$ 100$ million per year before tax by getting the better of each of the firm's previous deals with individual input suppliers. Layoffs and purchasing efficiencies realized can clearly explain the premium.

53. Berry tries unsuccessfully to buy Strawbridge \& Clothier. Equity $\$ 375$ million; debt $\$ 105$ million; premium $\$ 55$ million. No selloffs. No layoffs. Bidder has a board seat already and wants specific changes, such as financing of receivables and expansion of the discount chain, but the family in power refuses to do it. Looks like potential efficiency improvement opposed by the founding family. Berry may just be trying to put Strawbridge in play; there is evidence that he had little prospect of lining up necessary financing.

54. Bethlehem Steel buys Tull Industries as a white knight. Equity $\$ 96$ million; debt $\$ 10$ million; premium \$26 million. No selloffs. No layoffs (there are layoffs at Bethlehem, but they are probably not from Tull). Motives are probably Bethlehem's tax loss carryforwards and Tull's profitability, as well as strategic. However, a year after the acquisition, Tull is sold for $\$ 100$ million to Inland Steel, the original suitor, for $\$ 100$ million. Inland Steel also has tax losses. This is largely a tax deal with some strategic overtones.

55. Crane buys Unidynamics as a white knight. Equity $\$ 188.5$ million; debt $\$ 62.5$ million; premium $\$ 99$ million, and Crane loses $\$ 15$ million in value. Some selloffs; amounts not reported. No layoffs. Pension reversion of $\$ 18$ million. Diversification. Crane is after defense business of Unidynamics to augment its own and diversify away from cyclical high-fixed-cost industries in which it mostly operates.

56. GAF unsuccessfully tries to buy Union Carbide. Equity $\$ 5.6$ billion; debt $\$ 2.4$ billion; premium $\$ 1.34$ billion. Defensive response of Carbide is leveraged recapitalization/share buyback. Selloffs (mostly of sought after consumer brand names) are at least $\$ 4.5$ billion. Present value of savings from white-collar layoffs is $\$ 760$ million to $\$ 2$ billion. 
Remove $\$ 500$ million in excess assets from the pension plan. Interestingly, UC first buys back its equity at a high price and issues debt, but several months later issues new equity at low prices and retires debt. This has a massive cost to the company and shareholders who stayed on. White-collar layoffs and pension transfer can probably explain the premium, but selloffs of consumer business were probably profitable as well.

57. Clayton-Dubilier buys Uniroyal Tire in an LBO. Equity $\$ 746$ million; debt $\$ 255$ million; premium $\$ 234$ million. Also $\$ 300$ million underfunding in the pension plan. Selloffs of at least $\$ 935$ million, but the main tire division is kept. The tire division accounts for roughly one-third of operating profit in the pre-acquisition firm. Present value of savings from layoffs is $\$ 112$ million- $\$ 240$ million. A bustup, with important savings from layoffs.

58. Mesa Partners (Pickens) unsuccessfully tries to buy Unocal. Equity $\$ 9.2$ billion; debt $\$ 1.3$ billion; premium $\$ 2.21$ billion. Defensive response by Unocal is a discriminatory (against Pickens) leveraged recapitalization/share buyback. Take on $\$ 4.5$ billion in additional debt. Three years later, still has over $\$ 3$ billion in additional debt. Spin off 45 percent of oil and gas properties into master limited partnership to avoid corporate tax. Selloffs of under $\$ 40$ million. Layoffs of 600 employees, not counting early retirements, has the present value of savings between $\$ 45$ million and $\$ 120$ million. With early retirements and a hiring freeze, Forbes estimates $\$ 60$ million per year before tax, which is between $\$ 110$ million and $\$ 300$ million in present-value terms. Capital expenditures cut $\$ 500$ million per year, although this is quite typical for the whole industry during this period. Debt tax shield along with tax benefits from limited partnership can explain large part of premium given that Unocal is not paying down its debt quickly through asset selloffs, although the investment cut is probably also important.

59. Hanson Trust buys US Industries (response to MBO proposal at very low price). Equity $\$ 511$ million; debt $\$ 61$ million; premium $\$ 196$ million. Selloffs of $\$ 178$ million. Lays off 400 employees for saving of $\$ 30$ million- $\$ 80$ million in present value terms. This is a partial bustup with important savings from layoffs and possibly unused debt capacity (tax shields).

60. APL Partnership buys Van Dusen Air. Equity $\$ 63$ million; debt 
$\$ 14$ million; premium $\$ 14$ million. No layoffs. Sell for $\$ 101.5$ million an aviation service division that is 80 percent of revenues. It is sold to a strategic buyer. Keep remaining assets and put them in tax advantaged limited partnership. This is a bustup-tax savings situation.

61. Marine Midland Bank buys Westchester Financial Services. Equity $\$ 102$ million; premium $\$ 35$ million. No selloffs. No layoffs. Strategic.

62. Electrolux buys White Consolidated. Equity $\$ 743$ million; debt $\$ 180$ million; premium $\$ 164$ million. No selloffs. No layoffs. Strategic acquisition whereby Electrolux tries to enter U.S. appliance industry. 


\section{Comments and Discussion}

Comment by Gregg Jarrel: As George Stigler told me at the University of Chicago, "The plural of anecdote is data." This paper is an excellent illustration of that statement. Several conclusions come out of the authors' discussion that bear emphasis. The first is that loosening antitrust policies was the basic regulatory spur to the merger-and-takeover boom of the 1980s. I do not know if that is a valid conclusion, but it is the conclusion of this paper, and I agree with it.

The second conclusion is that the theory free cash flow receives is trivial. The authors concede that in the oil and gas industry the theory has some explanatory power, but that is as far as it goes. Michael Jensen's investigation of the industry motivated him to come up with the theory in the first place. He will be disappointed in the conclusion here, especially since in a recent article he argued that KKR is going to take over the United States. ${ }^{1}$

Those are my broad comments, but I have some specific questions and criticisms. Is the rate or the amount of selloffs directly related to the burden of leverage? How precisely is that measured? How far did the authors go to test that obvious empirical prediction?

I am also troubled by the measurement of premiums of the firms that remain independent. That is not nearly as easy as measuring the premiums of the takeover targets that are successfully bought out. There is a big bag of money, and it can be measured and the measurement expressed as a fraction of something. So, the researcher goes back in time to find the right base.

1. Jensen (1988). 
A firm that remains independent sometimes does so using a leveraged-recap transaction. But sometimes it defeats the offer by legal means. I wonder whether the cases here represent the former or the latter and whether the authors had any difficulties with them?

Also, did the authors find that the white knight cases had more frequent negative returns to bidders relative to the target gains? That finding comes out of the literature and is normally expressed as the "winner's curse", hypothesis-that the bidders that win auction contests for control do worse than the bidders that had negotiated agreements. Normally white knights, almost by definition, win auctions, at least as auctions are defined in this particular area.

A related question: are the conclusions sensitive to whether the authors used the takeover premiums to table 2 or the total in table 2? The total in table 2 takes account of the bidder returns, so the total takeover premium is measured. That is one potential measure as a base. The other measure nets out the return to the bidders.

It is my experience that bidder returns are measured with a great deal more error than are target returns. The best a researcher can do is hope to get large samples. With this particular approach in table 2 the authors are asking a great deal from their statistical methods on the bidder's side, to go in on a case-by-case basis and try to understand what the market had to say about the bidder's reaction to a particular event and then netting that out of the takeover premium.

One approach would be to say, "I do not know in any particular case if the market has any idea what it is doing in revaluing the bidder; I am going to assume the excess bidder return is zero and use the takeover premiums and the targets as a base.' It is a substitute approach. It would be nice to know if the conclusions remain valid under this substitute approach.

A related question is what is the relative size in these particular cases? How big are these bidders relative to the targets? There are a lot of data problems on the bidders' side. There are a lot of bidders that are not measurable because they are shell firms that do not really trade. The bidders that are measurable sometimes are very large relative to the target. A reader does not know what is being discounted with the bidders relative to the target. Maybe the bidders have been looking for firms that are like this target before, so the market has already discounted much of the information. You know all the old problems. 
Comment by Lawrence Summers: Sanjai Bhagat, Andrei Shleifer, and Robert Vishny are to be congratulated on an impressive paper that reveals a great deal of hard work. They have examined 62 takeovers, studying carefully the journalistic accounts of what took place.

Because I harbor the suspicion that Business Week and the New York Times may be more accurate in the coverage of corporate America than they are in their coverage of the nation's economics departments, it is with some scepticism that I think one has to take their results. Clearly if one wants to study 62 companies, there is no alternative to the approach the authors pursue, but my confidence in the results would have been greatly enhanced if they were also able to report on actual discussions and actual investigations with the people involved in some of their transactions so as to corroborate the method that was used.

The paper presents information that is new, bearing in one way or the other on three potential sources of value in takeovers: tax advantages, layoffs, and selloffs. I want to discuss their analysis of each and then offer some broader observations about the desirability or lack thereof of hostile takeovers as an agent of change.

The authors attribute some importance to the effects of tax advantages, stressing the role of debt and the interest deductability as a source of value in premiums and noting that the analysis by Auerbach and Reishus dismissed the effect of taxes. ${ }^{1}$ The analysis is largely suspect because Auerbach and Reishus focused on only a single tax effect: the ability to combine losses with profits. Everybody agrees that is not of great importance. I suspect that Bhagat, Shleifer, and Vishny here understate the importance of taxes for four reasons. First, contrary to their assertion, it does not really matter whether the debt involved in a takeover is paid back or is not paid back. Imagine that an acquisition is financed with debt and that the assets are then sold to some company that pays for them with cash out of its treasury. The government loses the interest deductions that used to cost the government revenue. The government now loses that revenue in the form of smaller interest earnings from the treasury of a company that made the acquisition. It is only if new equity is issued to finance acquisitions and is used to 
pay back debt that it is inappropriate to use the full permanent value of the debt in measuring tax advantages.

Second, modern financial technology permits interest deductions that substantially exceed true interest payments on high-technology bonds and other sophisticated financial instruments that carry high yields. The tax yield in the early years substantially exceeds the true interest cost. To that extent, the tax benefit of the deduction is understated by the authors' procedure of simply using the value of the debt. To think about that, just take the example of a 20-year junk bond that carries an 18 percent interest rate but which, nonetheless, has a negligible probability of defaulting in the first year. The true interest cost in the first year is 9 percent. The true deduction that is taken is a certain fraction of 18 percent. The value of the deduction exceeds the tax rate times the value of the actual interest payment. To that extent the tax saving is understated.

Third, the authors-because they cannot say much about it-slide quickly over the General Utilities aspect and the step-up of bases, which is regarded by practitioners as being of very considerable importance in a number of transactions.

Finally, they make no mention of the avoidance of dividend tax liabilities that takes place as a consequence of these repurchases and in a period when capital gains are preferentially taxed. They are a device for getting cash out of the corporate sector without paying the dividend taxes.

Taking all of those features together, I suspect the taxes are subsidizing these transactions to a rather greater extent than the authors suggest.

The authors come next to the question of layoffs. That is a slightly odd word for what is being discussed. It has to be acknowledged that if one believed that these transactions were substantially increasing efficiency, the way in which they would do that is by getting the same amount done with fewer people working. So, the reallocation of redundant employees would be another term that one could use.

The authors do not really pursue the idea that Andrei Shleifer and I had discussed in our earlier work, which was that there was an element of expropriation of stakeholders involved. The extent to which that is true depends on whether the displaced employees get new jobs at the same wage, or get new jobs at lower wages, or do not get new jobs at 
all. It would have been interesting to have had some hint or information about the extent to which the efficiency gained from these layoffs was matched by a loss to those who had been laid off.

Second, I suspect the authors understate the amount of reduced employment that is a consequence of these transactions. I take it that to qualify in their sample a firm has to announce in the Wall Street Journal that it is going to have a layoff. If it simply increases the generosity of its early retirement plan or increases employment less rapidly than it had intended, it does not qualify and probably will not get in the Wall Street Journal with that news. And to that extent it will be missed in their analysis.

Third, the authors' procedure for discounting the layoffs is odd. They use a 10 percent discount rate, and they say, "Well, you can get to that conclusion two ways. You can suppose that there is no inflation, that wages will not grow at the rate of inflation; or you can suppose that an 8 percent risk premium is appropriate.' However risky General Electric may be, I would assume that the cost saving from firing 1,000 people is roughly constant. It knows what that cost saving is, and it is not uncertain about what the benefit from that cash flow will be in the future. To that extent, the layoff should be discounted at a riskless rate. Since we are talking about that, changing the discount rate from 10 percent to 3 percent triples the amount, and that would be enough to substantially alter the authors' conclusions.

All of that said, what is on the other side? The authors acknowledge that they do not do much with the fact that presumably even the employees that could be laid off were contributing something beforehand. So, assuming that these employees were purely deadwood and all of the labor costs were treated as an efficiency improvement is probably not appropriate.

The authors also take no account of another possible expropriation, namely growth in wages that is slower than would otherwise have taken place, similarly for bargaining with suppliers and the like.

In the end there are substantial biases going in both directions, so it is difficult to know which way one would want to correct the authors' estimates. My own best guess would be that the value of the laborsaving costs is substantially greater than the authors suggest. However, there are probably also costs to not having that labor around any more, which the authors do not take any account of. 
The central conclusion of the paper, and by far the most interesting part, is the analysis summarized in table 8 . It is a commentary on both table 8 and tables 1 through 7 that about 60 percent of the value added of the paper is contained in table 8 , which illustrates that a large fraction of the assets that are involved in takeover transactions end up getting sold to other public corporations in industries closely related to those industries where the assets were already being deployed.

I think Gregg Jarrell was correct to suggest that the eclipse of the public corporation perhaps has lasted about as long as the typical eclipse lasts. The authors' analysis does suggest that these transactions do not primarily represent disincorporation. And there is a great deal of anecdotal evidence to suggest the the type of effect they are talking about is correctly observed. I recall the CEO of one major bank observing that "of course, our bank would be worth more broken up, but fortunately banking regulations make a hostile acquisition impossible, so we will remain a valuable organization for the foreseeable future."

Other chief operating officers are happy to explain in private that they have engaged in the exercise of shopping around individual divisions of their company and that when they do that, the combined value of individual divisions is two or three times the current value of their company. I usually refrain from asking them what they think about the market's implicit verdict on their managerial ability, sitting on top of these valuable assets.

It does seem as if busting up assets and allocating them separately to different people is a major source of value. That conclusion, I think, has not received enough attention and is the major contribution of the paper. The question one has to ask is: Why is this so? Why is it that reallocating assets produces such substantial contributions, apparently, or increases in value?

Let me just comment on four possible explanations. The first is what I would call the "winner's curse", aspect. Imagine that the Metropolitan Museum of Art could be put on sale in two different ways. In one case the whole museum would be put on sale. In the other case the paintings would be put on sale separately. I would imagine that the value fetched would be substantially greater in the second case because the people who liked a given painting would compete to buy it, and the total of these individual sales would be greater than that of a block purchase. So, too, if there are optimists about the steel industry or optimists about 
the oil industry. Selling steel assets and oil assets separately would increase the total value of the assets that can be realized. That may be why conglomerates carry such low values. There is no pure-play effect. Nobody is going to bet that everything IT\&T is doing is going to be good, but one can bet that car rental will be good or that some other division of the corporation will be good.

There is, however, an interesting conflict because it is perfectly possible that maximizing value by finding optimistic buyers for each class of assets will lead to a different conclusion than the conclusion of who can manage the assets best. It may well be that breakups that allow optimists about each individual part to own that part will increase the value at which the assets can be sold, even though people who buy them may not be those who are best able to operate them. Think about the sale of the paintings from the Metropolitan Museum. Some of the people who buy could be very poor at appreciating art.

A second hypothesis suggested by the conglomerate experience is that some of these transactions may involve transfer of earnings from situations in which they carry a high price-earnings ratio to situations where they carry a low ratio. I have no evidence on this point, but it does have the virtue that one could potentially get evidence on it. Supporting the conglomerate boom, in significant part, was that these conglomerates had high price-earnings ratios and other companies had low price-earnings ratios. When the conglomerates purchased companies and got more earnings, those extra earnings carried the same old price-earnings ratio that the conglomerate had had before. It is the same factor that explains why any American company that can will have a subsidiary issue equity in Japan right now.

Perhaps what is going on is that these transactions are taking the form of brokering earnings from places where they have a low priceearnings ratio to places where they have a high ratio. Those differences in price-earnings ratios may reflect rational expectations about the ability of management to increase earnings. They may simply reflect market conventions for valuing different companies that are slow to change. The same CEO who admitted to me that if his company sold its divisions separately the total price would be two or three times the company's current value also confessed to be spending some amount of his time endeavoring to speak with Standard and Poor about getting his company reclassified from one industry to another because the industry he wanted 
to be in had a price-earnings ratio that was 30 percent greater than the industry that he was now in. I think it is unlikely that that was an entirely futile exercise, if he could have pulled it off. And, to that extent, reallocations may be in order.

A third reason that reallocating assets produces increases in value is that the transactions are all coming at the hands of the people who put up the debt. Any idiot who called himself a condo minimum developer in Boston in the four years before a year and a half ago, or who called himself any kind of real estate developer and bought properties and painted them or did almost anything, made a spectacular rate of return. During the period when these takeovers yielded very substantial value, the stock market roughly tripled. If one simply bought the S \& P 500 stocks on 25 percent margins, one would have seen the money increase tenfold. Not even the KKR buyout fund has turned in such a performance.

I suspect that a large part of the success in buying divisions and selling those divisions separately has been partly the result of getting on a fast-moving escalator. But if the escalator slows down, who loses? It is the people who put up the debt and will not be in a position to collect. There is substantial evidence that, at least in the last six months, people who had put up debt in the preceding year are finding that action a very expensive mistake. So it may well be that a source of value in these transactions is that people have been allowed to borrow on margin to buy stock at an excessively favorable rate.

Finally, there is the question of market power, and here I would just highlight an observation that Michael Salinger made years ago. If you really think that firms have roughly constant returns of scale and that a little bit of market power will translate into a great deal of value, then let me give a simple example. It is not wildly wrong to say that the typical firm has a market value roughly equal to the value of its sales. Imagine that its elasticity of demand changes from five to six. That is not a change of spectacular magnitude. The change in the markup will be about 3.33 percent of sales. This percentage, for most companies, is a substantial share-perhaps a third, perhaps more-of profits, so the implied increase in market value would then be one-third to one-half. Thus even very small changes in the relevant elasticity of demand can account for very substantial increases in market value. And that lends some credence to the monopoly-power interpretation. 
I would be very surprised if a closer investigation than the one the authors carry out would suggest that a large fraction of the divisional sales that they report would in fact have been stopped by the antitrust authorities at the average moment from between 1950 and 1980. The suggestion that antitrust relaxation as a major force behind what has happened is unsupported by evidence does not really accord with my intuition.

Finally, about the public-policy tilt that all of this suggests: economists generally believe that interference with the markets should not be based on how good or how bad some trading commodity is but only on the external consequences of various activities. So, I looked at the analysis in this paper with a view to trying to determine what the external benefits and costs were, as distinct from the benefits and costs that were realized directly by the parties to these transactions. As best I could judge, whatever efficiency consequences there were in the form of economies of scale would be captured by the parties to takeover transactions. On the other hand, potential other sources of value-lost tax revenue, reductions in the value of human capital, sales people who were not smart and paid the wrong price-would all be imposing negative, external costs to those who were not involved in the transaction. And to that extent and to the extent that the authors have not suggested any important external benefits to these transactions, it seems to me that the analysis pointed in the direction of a policy tilt toward reducing the number of hostile takeovers.

General Discussion: An issue that particularly interested the participants was the increased postmerger profits that seemed to result from a horizontal acquisition. Lawrence White alleged that it is often difficult to tell whether these higher profits come from increased market power or decreased costs. This was a serious issue for many of the participants because of the implications for antitrust enforcement. According to White the authors claim that antitrust enforcement virtually stopped in the 1980s. If these increased profits are, in fact, coming from enhanced market power, this brings into question the policy of reduced antitrust enforcement. If, on the other hand, they are coming from decreased costs - from efficiency gains - then the new antitrust policies might be performing as they were intended to. White claimed that the 1982 and 1984 merger guidelines rationalized antitrust enforcement, forcing it to 
focus on where the threats of market power really came from. Andrei Shleifer said that the data used for the paper did not allow for a distinction to be made between monopoly power and efficiency gains.

Michael Whinston wanted more information about what features of hostile takeovers made them different from friendly ones, since the paper pointed out that, by and large, both occur for strategic reasons. He was interested in a more substantial definition of the term "strategic takeover." According to Whinston, the authors apply this term to takeovers occurring for seemingly different reasons: monopolization, vertical integration, R\&D advantages, and so forth. Shleiffer replied by saying that the overwhelming majority of things that the paper defines as "strategic" involve horizontal moves, with only one or two concerned with vertical integration.

Whinston was also interested in the industrial organization of the brokerage market. He wondered if the final buyers of the firms involved in takeovers made money on the transaction, or if the brokers were able to successfully extract all of the rents. He suggested that the type of strategic acquisition - that is, monopolization or strategic advantagemight have an effect on the amount of the rents that brokers would be able to extract.

Oliver Williamson said that the evidence brought out in the paper supports the theory of complacent management. He said that it is difficult for management to "run a tight ship" for an extended period of time. When aggressive capital markets see this, a takeover occurs, and belt-tightening is instituted, which accounts for the takeover premiums.

Richard Caves said that the takeovers appear to be a mechanism by which businesses are transferred from corporations with which they have a bad fit to corporations that can better manage them. Shleiffer agreed with this and said that the evidence presented in the paper was consistent with the idea of improving efficiency by transferring assets to better managers in the same line of business as those assets.

Margaret Blair said that more attention must be given to free-cashflow theory. She asserted that free cash flow was tied to the authors' claim that the abrogation of implicit employment contracts is a source of takeover premiums. Blair said breaking such implicit contracts would be more likely to occur when those contracts become inconsistent with profit maximization, that is, when they represent inappropriate use of free cash flow. 
Martin Baily asked if the journalistic accounts used in the paper constituted data. Sanjai Bhagat responded by saying that they had used all publicly available published reports on layoffs, selloffs, and so forth. These included newspapers, popular and trade magazines, proxy statements, annual reports, $10 \mathrm{~K}$ 's, and other sources.

\section{References}

Asquith, Paul, and Thierry A. Wizman. 1989. "Event Risk, Wealth Redistribution and the Return to Existing Bondholders in Corporate Buyouts." Mimeo, Massachusetts Institute of Technology (February).

Auerbach, Alan, and David Reishus. 1988. "The Effects of Taxation on the Merger Decision." In Corporate Takeovers: Causes and Consequences, edited by A. J. Auerbach. University of Chicago Press.

$\rightarrow$ Bhide, Amar. 1989. "The Causes and Consequences of Hostile Takeovers." Continental Bank Journal of Applied Corporate Finance 2:36-59.

$\rightarrow$ Bradley, Michael, Anand Desai, and E. Han Kim. 1988. "'Synergistic Gains from Corporate Acquisitions and Their Division between the Stockholders of Target and Acquiring Firms."' Journal of Financial Economics 21 (May): $3-40$.

Brown, Charles, and James L. Medoff. 1988. "The Impact of Firm Acquisitions on Labor." In Corporate Takeovers: Causes and Consequences, edited by A. J. Auerbach. University of Chicago Press.

Bureau of Labor Statistics. 1987. Employment and Earnings. Washington: Department of Labor. January.

$\rightarrow$ Eckbo, B. Espen. 1983. "Horizontal Mergers, Collusion, and Stockholder Wealth.' Journal of Financial Economics 11 (April):241-74.

Jensen, Michael C. 1984. "Takeovers: Folklore and Science." Harvard Business Review 84 (November-December):109-21.

- 1986. "Agency Costs of Free Cash Flow, Corporate Finance, and Takeovers." American Economic Review 76:323-29.

- 1988. "Takeovers: Their Causes and Consequences." Journal of Economic Perspectives 2 (Winter):21-48.

Kaplan, Steven N. 1989. "Management Buyouts: Evidence on Taxes as a Source of Value." Journal of Finance 44 (July):611-32.

- 1990. "The Effects of Management Buyouts on Operations and Value." Journal of Financial Economics (forthcoming).

Kaplan, Steven N., and Michael S. Weisbach. 1990. "Acquisitions and Divestitures: What is Divested and How Much Does the Market Anticipate?", Mimeo, University of Chicago. 
LeBaron, Dean, and Lawrence Speidell. 1987. "Why Are the Parts Worth More than the Whole? 'Chop Shop,' A Corporate Valuation Model.', In The Merger Boom. Federal Reserve Bank of Boston.

Lichtenberg, Frank, and Donald Siegel. 1988. "The Effect of Takeovers on the Employment and Wages of Central Office and Other Personnel.' Mimeo, Columbia University.

Morck, Randall, Andrei Shleifer, and Robert W. Vishny. 1988. "Characteristics of Targets of Hostile and Friendly Takeovers.' In Corporate Takeovers: Causes and Consequences, edited by A. J. Auerbach. University of Chicago Press.

- 1989. “Alternative Mechanisms for Corporate Control.' American Economic Review 79 (September):842-52.

1990. “Do Managerial Objectives Drive Bad Acquisitions?', Journal of Finance 45 (March):31-48.

Nathan, Felicia. 1987. “Analyzing Employers' Compensation Costs.' Monthly Labor Review (October):3-11.

Pontiff, Jeffrey, Andrei Shleifer, and Michael Weisbach. 1989. “Reversions of Excess Pension Assets after Takeovers.' Mimeo, University of Rochester.

Porter, Michael E. 1987. "From Competitive Advantage to Corporate Strategy." Harvard Business Review, 65 (May-June):43-59.

Ravenscraft, David J., and F. M. Scherer. 1987. Mergers, Selloffs and Economic Efficiency. Brookings.

Rosett, Joshua. 1989. "Do Breaches Explain Takeover Premiums? The Evidence on Union Wages.' Mimeo, National Bureau of Economic Research (November).

Servaes, Henri. 1989. “Tobin's Q, Agency Costs, and Corporate Control.' Mimeo, Center for Research in Security Prices, University of Chicago.

Shleifer, Andrei, and Lawrence H. Summers. 1988. " Breach of Trust in Hostile Takeovers.' In Corporate Takeovers: Causes and Consequences, edited by A. J. Auerbach. University of Chicago Press.

Stigler, George J. 1950. "Monopoly and Oligopoly by Merger.' American Economic Review (Papers and Proceedings, 1951) 40 (May):23-34.

$\rightarrow$ Stillman, Robert. 1983. "Examining Antitrust Policy towards Horizontal Mergers.' Journal of Financial Economics 11 (April):225-40. 